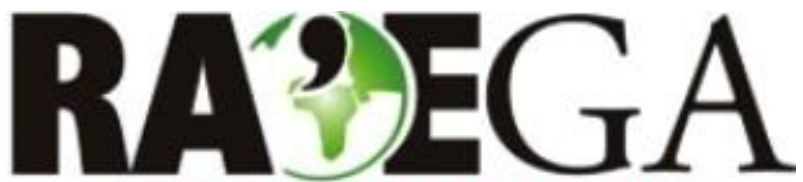

O ESPAÇO GEOGRÁFICO EM ANÁLISE

\title{
ÍNDICE DE POSIÇÃO TOPOGRÁFICA (IPT) PARA CLASSIFICAÇÃO GEOMORFOMÉTRICA DAS FORMAS DE RELEVO NO ESTADO DO PARANÁ - BRASIL
}

\author{
TOPOGRAPHIC POSITION INDEX (TPI) FOR GEOMORPHOMETRIC CLASSIFICATION OF LANDFORMS IN \\ THE STATE OF PARANÁ - BRAZIL. \\ Claudinei Taborda da Silveira ${ }^{1}$, Ricardo Michael Pinheiro Silveira ${ }^{2}$
}

\section{RESUMO}

A geomorfometria tem favorecido o tratamento quantitativo nos estudos e representação das formas do relevo, sobretudo a partir de parâmetros calculados de Modelos Digitais do Terreno (MDTs). Nessa perspectiva, o trabalho teve como objetivo realizar a classificação geomorfométrica automatizada das formas de relevo do Paraná, Brasil, por meio da aplicação do Índice de Posição Topográfica (IPT), seguido da avaliação de sua distribuição nas subunidades morfoesculturais do Mapa Geomorfológico do Paraná e análise da fidedignidade classificatória do método apoiado no reconhecimento de campo em cinco áreas amostrais distribuídas no território paranaense. 0 MDT com resolução de $20 \mathrm{~m}$, foi interpolado pelo método Topogrid da base planialtimétrica nas escalas 1:50.000 e 1:25.000. Conforme proposta aplicada, o IPT foi derivado da mensuração entre a diferença da elevação de um ponto central com a média da elevação do seu entorno a partir de um raio predeterminado. As dez formas de relevo resultantes são decorrentes da discretização amparada pelos valores de desvio padrão e da combinação de dois IPTs (um de detalhe, com janela circular de leitura com raio de 8 células, e outro generalizado com raio de 79 células). Os resultados demonstraram, numa perspectiva regional, que o emprego do IPT permitiu identificar arranjos distintos com padrões de formas de relevo predominantes que foram coincidentes com os limites préestabelecidos das subunidades morfoesculturais do estado. Na perspectiva local, as dez formas de relevo mapeadas foram condizentes com a realidade de campo em quatro recortes, sendo que um deles demonstrou limitação na representação do planalto de baixa declividade da região noroeste com as planícies, o que retrata a dificuldade da plena representação do relevo considerando os mesmos parâmetros indistintamente em todo o Paraná..

PALAVRAS-CHAVE: Análise Digital do Relevo; Geomorfometria; Modelo Digital do Terreno; Geomorfologia do Paraná.

\section{ABSTRACT}

The geomorphometry has favored the quantitative treatment in studies and representation of the landforms, mainly from calculated parameters of Digital Terrain Models (DTMs). From this perspective, this paper aims to carry out the automated geomorphometric classification of the landforms in the state of Paraná, Brazil, by applying the Topographic Position Index (TPI); followed by the evaluation of its distribution in the morpho-sculptural subunits in Paraná's Geomorphological Map, and an analysis of the classification reliability of the method supported by the field recognition in five sampled areas distributed throughout the state territory. The $20 \mathrm{~m}$ resolution DTM was interpolated by the Topogrid method of the planialtimety baseline in the 1:50,000 and 1:25,000 scales. According to the applied proposal, TPI has derived from the measurement between the elevation difference of a central point and the elevation average of its neighboring from a predetermined radius. The 10 landforms resulting from the discretization supported by the standard deviation values and the combination of two TPIs (with a circular scan window with a radius of 8 cells, and a generalized one with a radius of 79 cells). Results showed, in a regional perspective, that the TPI use allowed identifying distinct arrangements with patterns of prevailing landforms that coincided with the pre-established boundaries of the morpho-sculptural subunits in the state. In local perspective, the ten mapped landforms were consistent with the field reality in four areas, wherein one of them showed limitation regarding the representation of the small slope plateau in the northwest region with plains, which depicts the difficulty of a full representation of the relief, indistinctly considering the same parameters all over Paraná state.

KEY-WORDS: Digital Landform Analysis; Geomorphometry; Digital Terrain Model; Geomorphology of Paraná state.

Recebido em: 10/04/2017

Aceito em: 20/06/2017

\footnotetext{
${ }^{1}$ Universidade Federal do Paraná ,Curitiba/PR, e-mail: claudinei.ufpr@yahoo.com.br

${ }^{2}$ Universidade Federal do Paraná ,Curitiba/PR, e-mail: ricardomichaelps@gmail.com
} 


\section{SILVEIRA,C.T. e SILVEIRA, R.M.P. \\ ÍNDICE DE POSIÇÃO TOPOGRÁFICA (IPT) PARA CLASSIFICAÇÃO GEOMORFOMÉTRICA DAS FORMAS DE RELEVO NO ESTADO DO PARANÁ - BRASIL}

\section{INTRODUÇÃO}

As ferramentas empregadas na cartografia geomorfológica que prevalecem no início do século XXI, se amparam fortemente na modelagem digital do relevo (ou modelagem digital do terreno). Seu uso é favorecido pelos avanços na ciência da computação e disponibilidade de hardwares e softwares com capacidade de armazenamento e processamento crescentes; pelos progressos das geotecnologias, se destacando os Sistemas de Informações Geográficas (SIGs) e as técnicas de Processamento Digital de Imagem (PDI) voltadas para análise espacial do relevo; e devido à disseminação de Modelos Digitais de Elevação (MDE) com recobrimento global, alguns gratuitos - caso dos dados altimétricos disponibilizados pelos projetos SRTM (Shuttle Radar Topographic Mission) e Aster-GDEM (Advanced Spaceborne Thermal Emission and Reflection RadiometerGlobal Digital Elevation Model).

A modelagem digital do terreno tem favorecido o tratamento quantitativo nos estudos e representação das formas do relevo. Apesar da abordagem quantitativa já ser consagrada na geomorfologia, com designação de geomorfometria, cuja definição já era apresentada em Chorley (1957), como a ciência que trata da geometria da paisagem e das tentativas de descrever quantitativamente a superfície da Terra. Na atualidade, amparada fortemente na modelagem digital, a geomorfometria é definida como a ciência da análise quantitativa da superfície terrestre (PIKE, 2000), que configura uma moderna abordagem analítico-cartográfica para representação da topografia da Terra por meio da manipulação computacional de valores de elevação do terreno (TOBLER, 2000).

As operações elementares na geomorfometria constituem a obtenção de parâmetros calculados a partir dos Modelos Digitais do Terreno (MDTs), (PIKE, 2009); enquanto a parametrização da morfologia do relevo via SIG é o processo de extração de atributos quantitativos da topografia de um MDT
(HENGL, 2003) - cuja sistematização pode ser designada como modelagem do terreno (LI et al., 2005), análise do terreno (WILSON; GALLANT, 2000), ciência da topografia (MARK; SMITH, 2004) e análise digital do relevo (SILVEIRA, 2010).

Os parâmetros obtidos dos MDTs constituem descritores representativos de mensurações quantitativas das formas de relevo. $\mathrm{Na}$ literatura recebem distintas designações, se destacando: atributos topográficos (MOORE et al., 1991, 1993; WILSON; GALLANT, 2000; CHAGAS, 2006; SILVEIRA et al., 2012, 2013), parâmetros das formas do relevo (SPEIGHT, 1968), variáveis topográficas (VALERIANO, 2003; VALERIANO; CARVALHO JÚNIOR, 2003), variáveis morfométricas (SHARY et al, 2002; VALERIANO, 2005), variáveis geomorfométricas (MUÑOZ, 2009; BISPO et al., 2009), informações do terreno (MARTINONI, 2002), atributos do terreno (PENNOCK, 2003; CÁTEN, 2009; VASCONCELOS et al., 2012), atributos geomorfométricos (SCHMIDT; DIKAU, 1999) e atributos do relevo (IPPOLITI et al., 2005; SIRTOLI et al., 2008).

Segundo Minar e Evans (2008), hodiernamente, o principal desafio da modelagem digital do terreno é a supressão das imprecisões e subjetividades verificadas nos mapeamentos geomorfológicos tradicionais, possibilitando, por outro lado, a realização de levantamentos geomorfológicos preliminares com baixo custo operacional, com exequibilidade e representatividade da paisagem; devendo, entretanto, se pautar em procedimentos metodológicos rigorosos para que a classificação resultante seja eficiente (SILVEIRA; SILVEIRA, 2015, 2016).

No arcabouço bibliográfico, diversos autores apontam as vantagens da classificação digital do relevo (WOOD, 1996; MACMILLAN et al., 2000; WILSON; GALLANT, 2000; ROMSTAD, 2001; VALERIANO, 2004; DRAGUT; BLASCHKE, 2006; IWAHASHI ; PIKE, 2007; KLINGSEISEN et al., 2007; GROHMANN et al., 2008; SAADAT et al., 2008; WILSON, 2012; SILVEIRA et al., 2012), sobretudo em função da minimização da subjetividade em relação aos método 


\section{SILVEIRA,C.T. E SILVEIRA, R.M.P. \\ ÍNDICE DE POSIÇÃO TOPOGRÁFICA (IPT) PARA CLASSIFICAÇÃO GEOMORFOMÉTRICA DAS FORMAS DE RELEVO NO ESTADO DO PARANÁ - BRASIL}

convencionais qualitativos de classificação, da facilidade em comparação aos resultados derivados de diferentes conjuntos de dados e da redução do tempo de delineação de unidades.

\begin{tabular}{|c|c|c|c|}
\hline \multicolumn{2}{|c|}{ Corroborando } & as & preocupações \\
\hline ionadas, & os & principais & $\mathrm{me}$ \\
\hline volvidos & & para & classi \\
\hline
\end{tabular}
geomorfométrica utilizam chaves de classificação dos atributos topográficos e consideram um conjunto de regras preestabelecidas, considerando os fatores: escala, tamanho e forma. (VASCONCELOS et al., 2012).

Exemplificando, Iwahashi e Pike (2007) propõem a classificação do relevo por meio de uma árvore de decisões estruturada por três variáveis morfométricas, aplicando-a em três escalas distintas: a) o distrito de Shimukappu, no Japão (MDE com $55 \mathrm{~m}$ ); b) todo território japonês (MDE com 270 m); e c) toda extensão continental da Terra (MDE com $1 \mathrm{~km}$ de resolução). No Brasil esta proposição foi empregada por Silveira et al. (2014) para identificação de unidades de relevo no estado do Paraná, por Trentin et al. (2015) para compartimentação geomorfométrica direcionada ao zoneamento do relevo em bacia hidrográfica situada no oeste do estado do Rio Grande do Sul, e por Gomes et al. (2016) para compartimentação geomorfométrica de unidades de relevo, utilizando como recorte espacial duas cartas topográficas que compõe articulação sistemática do estado do Paraná.

Reuter (2009) propõe a automatização, em ambiente SIG, da taxonomia proposta por Dikau (1991, 1995), que, por sua vez, consiste em sistema de classificação composta por três níveis hierárquicos, estes resultantes da combinação de atributos topográficos; tendo sido empregado na classificação automatizada de formas do relevo do estado do Paraná (SILVEIRA; SILVEIRA, 2015a) e da região central da Serra do Mar Paranaense (SILVEIRA, 2015); e na classificação de padrões de formas semelhantes do relevo no planalto de Poços de Caldas/MG (TINÓs et al., 2014).

A automatização geomorfométrica de formas de relevo foi, igualmente, preocupação de Vasconcelos et al. (2012), aplicando no Parque Nacional da Serra da Canastra (MG), um sistema arquitetado em duas etapas sequenciais: a primeira direcionada por classificação em árvore de decisão, com uso de dados de altitude e de declividade; e a segunda derivada da submissão da árvore de decisão ao classificador espectral Spectral Angle Mapper (SAM), empregando atributos de curvatura.

$$
\text { Jasiewicz e Stepinski }
$$
estabeleceram parametrização geomorfológica automatizada pautando-se nos denominados geomorphons - técnica que possui como peculiaridade a classificação dos elementos de relevo (dez classes mais comuns) através do emprego de ferramentas de visão computacional, em substituição à combinação de variáveis extraíveis de um MDT. No cenário brasileiro, tal proposta foi aplicada por Robaina et al. (2016) para compartimentação do estado do Rio Grande do Sul.

No contexto da classificação automatizada do relevo direcionada ao presente trabalho, evidencia-se o método proposto por Weiss (2001), que permite, mediante o emprego do Índice de Posição Topográfica ${ }^{3}$ (IPT), a identificação de 10 classes de relevo: 1) Fundos de vales com forte incisão da drenagem e cânions; 2) Vales rasos e áreas de drenagem situadas no terço médio das vertentes; 3) cabeceiras de drenagens; 4) áreas situadas nos terços inferiores das vertentes ou vales abertos e em forma de $U$; 5) áreas planas; 6) áreas situadas nas posições intermediárias das vertentes; 7) áreas situadas nas posições superiores das vertentes, patamares superiores ou mesas; 8) interflúvios secundários ou situados nas porções intermediárias das vertentes; 9) topos rebaixados, interflúvios, cristas intermediárias ou morros em áreas planas; 10 ) interflúvios elevados ou na forma de cristas elevadas e topos elevados.

O emprego do método em questão foi aplicado na classificação morfológica da República do Uruguai por Silveira e Silveira (2014), enquanto que no território brasileiro pode ser exemplificado pelo mapeamento

\footnotetext{
${ }^{3}$ A denominação originalmente empregada por Weiss (2001) é Topographic Position Index (TPI).
} 


\section{SILVEIRA,C.T. E SILVEIRA, R.M.P. \\ ÍNDICE DE POSIÇÃO TOPOGRÁFICA (IPT) PARA CLASSIFICAÇÃO GEOMORFOMÉTRICA DAS FORMAS DE RELEVO NO ESTADO DO PARANÁ - BRASIL}

geomorfométrico de bacia hidrográfica situada no município de Blumenau, estado de Santa Catarina (LANGE FILHO; SILVEIRA, 2015; LANGE FILHO, 2016); por recortes espaciais concernentes à região central da Serra do Mar Paranaense (SILVEIRA, 2015; SILVEIRA; SILVEIRA, 2016); e em setor de transição entre esta última e o Primeiro Planalto Paranaense (NEUMAN, 2017).

Frente ao exposto, o objetivo do presente trabalho é realizar a classificação geomorfométrica automatizada das formas de relevo no estado do Paraná (Brasil), considerando a distribuição de classes derivadas do IPT dentro dos limites das subunidades morfoesculturais (escala 1: 250.000), anteriormente definidas por Santos et al. (2006); bem como avaliar a fidedignidade classificatória do referido método em cinco recortes de detalhamento amostral, que agregam, por sua vez, diferentes etapas de reconhecimento in loco de aspectos geomorfológicos superlativos, considerados, portanto, amplamente representativos no âmbito da proposta apresentada.

\section{MÉTODO}

\section{OBTENÇÃO DO MODELO DIGITAL DO TERRENO} (MDT)

Apesar de algumas vezes ser controverso na literatura o emprego dos termos Modelo Digital de Elevação (MDE) e Modelo Digital do Terreno (MDT), (LI et al., 2005; ZHOU et al., 2008; PIKE et al., 2009), a compreensão que foi adotada é em acordo com El-Sheimy et al. (2005), na qual os MDEs expressam os valores altimétricos contemplando os objetos existentes na superfície e os MDTs se referem aos valores altimétricos do terreno, desconsiderando qualquer objeto sobre ele. Portanto, a opção foi pelo emprego de um MDT obtido das informações das cartas topográficas do levantamento sistemático.

O MDT foi interpolado a partir do método Topogrid (HUTCHINSON, 1988) disponível no software ArcGIS 10.1, utilizando-se como dados vetoriais de entrada: curvas de nível, pontos cotados e hidrografia. Estes dados foram digitalizados das 86 cartas topográficas do DSG e IBGE na escala 1:25:000, concernentes à porção leste do estado do Paraná (Planície Litorânea, Serra do Mar e parte do Primeiro Planalto); e das 297 cartas que compreendem as demais áreas do estado, na escala 1:50.000. Após compilação e ampla correção vetorial, tais bases necessitaram ser fragmentadas em oito porções do estado, visando otimizar seu processamento computacional.

Ainda que o estado do Paraná disponha de MDEs globais, como o SRTM (90m v1, 90m v4, $30 \mathrm{~m}$ v1, banda-C versão 4 e banda X) e Aster GDEM, a adoção do MDT interpolado a partir da base planialtimétrica pelo método Topogrid se deu em função da melhora de resolução, da consistência hidrológica e da representação que desconsidera objetos na superfície (como copas de árvores ou edificações) em relação aos MDEs globais, conforme análise comparativa realizada por Silveira e Silveira (2015b).

A etapa de escolha do tamanho da célula do MDT seguiu recomendações de Hengl (2006), considerando duas propostas: cartográfica e de complexidade do terreno. A primeira, que se refere à escala dos dados de entrada do MDT, se apoia no conceito cartográfico de "delineação mínima legível" (VINK, 1975) e tem como tamanho recomendável 0,5 milímetros no mapa. Para a escala 1:50.000, a célula deveria, então, ter 25 metros; enquanto para a escala 1:25.000, 12,5 metros.

A segunda proposta, que considera as características topográficas locais, é resultante da relação entre tamanho do recorte de estudo e extensão das curvas de nível, conforme equação 1:

$c<\frac{A}{2 \sum I}$

onde c é o tamanho da célula, $A$ é a área total do recorte e $\sum l$ é o somatório do comprimento de todas as curvas de nível deste mesmo recorte.

Aplicou-se esta mesma formulação para os $5 \%$ de área que possuem maior concentração de curvas de nível (equação 2), a fim de verificar o tamanho mínimo de célula adequado para a 


\section{ÍNDICE DE POSIÇÃO TOPOGRÁFICA (IPT) PARA CLASSIFICAÇÃO GEOMORFOMÉTRICA DAS FORMAS DE RELEVO NO ESTADO DO PARANÁ - BRASIL}

representação de porções com maior variação de relevo.

$c>\frac{A(5 \%)}{2 \cdot \sum l(5 \%)}$

Para a área total, o resultado da equação indicou que a célula deve ter valor inferior a 58 metros; para os $5 \%$ de área com maior rugosidade (porção da Serra do Mar), o valor indicado foi de superior a 13 metros.

Considerando as indicações dessas duas propostas (cartográfica e de complexidade do terreno), o tamanho de célula do MDT para todo o estado foi definido em $20 \times 20$ metros.

\section{APLICAÇÃO DO ÍNDICE DE POSIÇÃO TOPOGRÁFICA}

O Índice de Posição Topográfica (IPT), proposto por Weiss (2001), é derivado de um algoritmo que mensura a diferença entre a elevação de um ponto central $\left(Z_{0}\right)$ e a média da elevação do seu entorno a partir de um raio predeterminado $\left(Z_{0}\right)$, descrito na equação 3 :

$I P T=Z_{0}-\bar{Z}$

A análise de vizinhança pode ser feita por uma janela circular (empregada no presente trabalho), anular (proposta original), retangular ou irregular.

Os valores positivos obtidos pelo IPT representam locais que são mais elevados que a média do seu entorno, caracterizando, por exemplo, as cristas. Os valores negativos, por sua vez, representam os locais mais rebaixados em relação à sua vizinhança, caracterizando vales ou depressões. Já os valores próximos a zero obtidos pelo IPT representam as superfícies de declive constante, destacando-se as áreas planas (Figura 1)

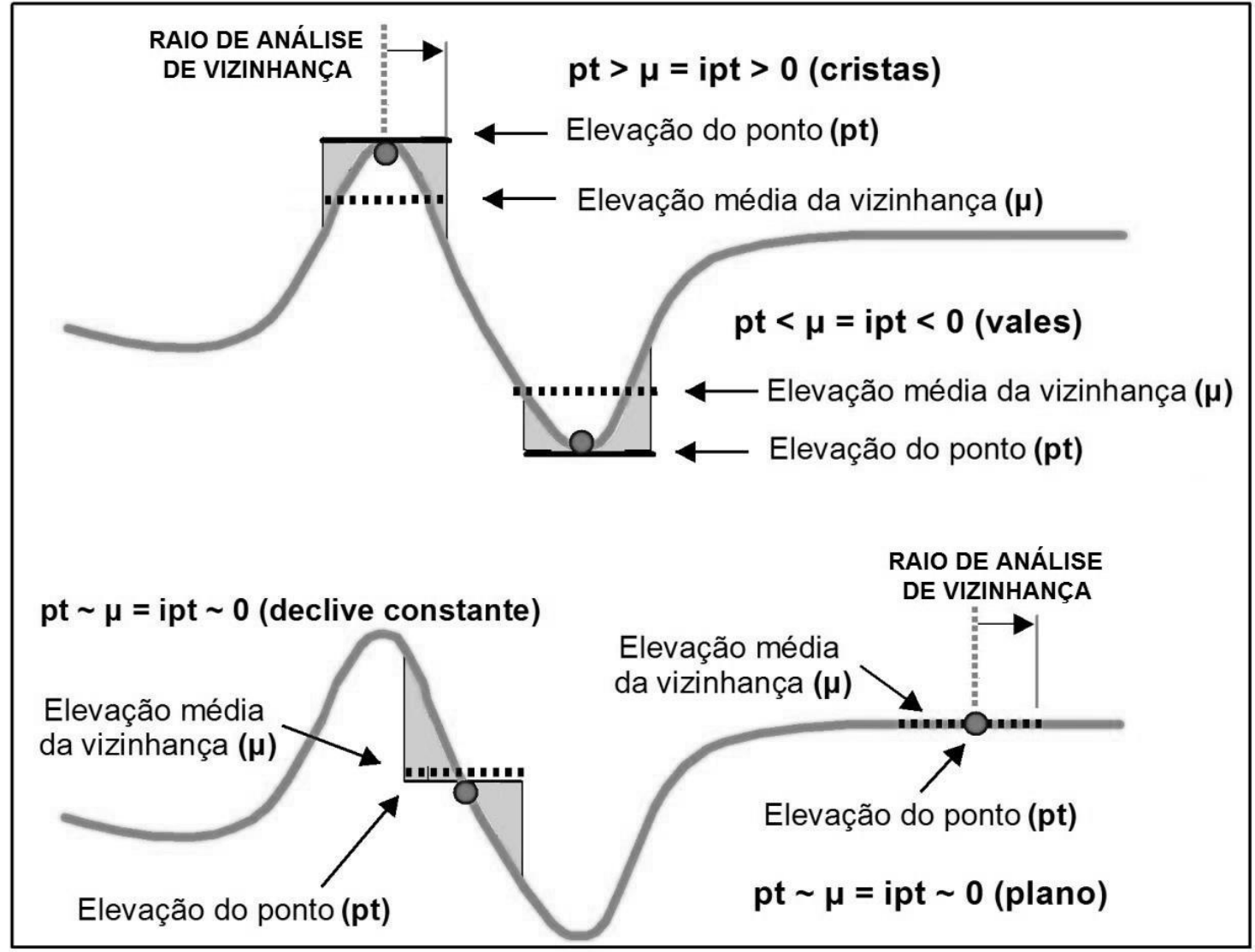

Figura 01 - Índice de Posição Topográfica (IPT). Fonte: Adaptado de Weiss (2001).

Wilson e Gallant (2000, p. 74), apresentando a mesma equação, definem o cálculo como "Diferença da Elevação Média". Weiss (2001), entretanto, propõe uma 


\section{SILVEIRA,C.T. E SILVEIRA, R.M.P. \\ ÍNDICE DE POSIÇÃO TOPOGRÁFICA (IPT) PARA CLASSIFICAÇÃO GEOMORFOMÉTRICA DAS FORMAS DE RELEVO NO ESTADO DO PARANÁ - BRASIL}

discretização a partir do valor de desvio padrão da matriz resultante para a determinação de classes morfológicas.

A classificação considera o particionamento e combinação de duas matrizes do IPT com variação no tamanho do raio de análise de vizinhança: uma de mais detalhe e outra mais generalizada, resultando em até 10 distintas formas de relevo (Quadro 1). A designação originalmente proposta foi traduzida ${ }^{4}$ e adaptada para as feições de relevo presentes na área de estudo.

Quadro 01 - Parâmetros combinatórios do IPT detalhado e generalizado para classificação das formas de relevo.

\begin{tabular}{|c|c|c|}
\hline Formas de relevo & \multicolumn{2}{|r|}{ Parâmetros } \\
\hline \multirow{2}{*}{$\begin{array}{l}\text { Fundos de vales com forte } \\
\text { incisão da drenagem e canyons }\end{array}$} & IPT detalhado & $\leq-1$ desvio padrão \\
\hline & IPT generalizado & $\leq-1$ desvio padrão \\
\hline \multirow{2}{*}{$\begin{array}{c}\text { Vales rasos e áreas de } \\
\text { drenagem situadas no terço } \\
\text { médio das vertentes }\end{array}$} & IPT detalhado & $\leq-1$ desvio padrão \\
\hline & IPT generalizado & $>-1$ desvio padrão e $<1$ desvio padrão \\
\hline \multirow{2}{*}{ Cabeceiras de drenagens } & IPT detalhado & $\leq-1$ desvio padrão \\
\hline & IPT generalizado & $\geq 1$ desvio padrão \\
\hline \multirow{2}{*}{$\begin{array}{c}\text { Áreas situadas nos terços } \\
\text { inferiores das vertentes ou vales } \\
\text { abertos e em forma de } U\end{array}$} & IPT detalhado & $>-1$ e $<1$ desvio padrão \\
\hline & IPT generalizado & $\leq-1$ desvio padrão \\
\hline \multirow{2}{*}{ Áreas planas } & IPT detalhado & $>-1$ e $<1$ desvio padrão \\
\hline & IPT generalizado & $>-1$ e $<1$ desvio padrão e declividade $\leq 5$ graus \\
\hline \multirow{2}{*}{$\begin{array}{l}\text { Áreas situadas nas posições } \\
\text { intermediárias das vertentes }\end{array}$} & IPT detalhado & $>-1$ e $<1$ desvio padrão \\
\hline & IPT generalizado & $>-1$ e $<1$ desvio padrão e declividade $>5$ graus \\
\hline \multirow{2}{*}{$\begin{array}{c}\text { Áreas situadas nas posições } \\
\text { superiores das vertentes, } \\
\text { patamares superiores ou mesas }\end{array}$} & IPT detalhado & $>-1$ e $<1$ desvio padrão \\
\hline & IPT generalizado & $\geq 1$ desvio padrão \\
\hline \multirow{2}{*}{$\begin{array}{l}\text { Interflúvios secundários ou } \\
\text { situados nas porções } \\
\text { intermediárias das vertentes }\end{array}$} & IPT detalhado & $\geq 1$ desvio padrão \\
\hline & IPT generalizado & $\leq-1$ desvio padrão \\
\hline \multirow{2}{*}{$\begin{array}{c}\text { Topos rebaixados, interflúvios, } \\
\text { cristas intermediárias ou morros } \\
\text { em áreas planas }\end{array}$} & IPT detalhado & $\geq 1$ desvio padrão \\
\hline & IPT generalizado & $>-1$ e $<1$ desvio padrão \\
\hline \multirow{2}{*}{$\begin{array}{l}\text { Interflúvios elevados ou na } \\
\text { forma de cristas elevadas e } \\
\text { topos elevados }\end{array}$} & IPT detalhado & $\geq 1$ desvio padrão \\
\hline & IPT generalizado & $\geq 1$ desvio padrão \\
\hline
\end{tabular}

Como o IPT é diretamente afetado pelo fator de escala (ou seja, da análise de vizinhança para o cálculo da elevação média), os valores resultantes do índice variam de acordo com os valores de raio adotados. A etapa de definição do raio de análise de vizinhança, portanto, conforme apontam Tagil e Jenness (2008) e De Reu et al. (2013), deve estar associada ao nível de detalhe pretendido pelo pesquisador.

Nesse sentido, para evitar a atribuição arbitrária e subjetiva do raio de análise de vizinhança, utilizou-se como referência quantitativa a classificação taxonômica de Tricart (1965), que atribui valores aproximados de área para feições geomorfológicas adequadas à determinada ordem de grandeza espacial e temporal .

Assim, utilizou-se como referência a transição da $\mathrm{V}$ para a VI ordem, destacada no quadro 2. Para o IPT de raio mais generalizado a referência foi a área de $10 \mathrm{~km}^{2}$, que considerando o tamanho de célula de 20 metros do MDT

\footnotetext{
${ }^{4}$ A designação originalmente proposta por Weiss (2001) para designação das formas de relevo (landforms) é: 1) canyons, deeply incised streams; 2) midslope drainages, shallow valleys; 3) upland drainages, headwaters; 4) U-shape valleys; 5) plains; 6) open slopes; 7) upper slopes, mesas; 8) local ridges/hills in valleys; 9) midslope ridges, small hills in plains; 10) mountain tops, high ridges.
} 


\section{SILVEIRA,C.T. E SILVEIRA, R.M.P. \\ ÍNDICE DE POSIÇÃO TOPOGRÁFICA (IPT) PARA CLASSIFICAÇÃO GEOMORFOMÉTRICA DAS FORMAS DE RELEVO NO ESTADO DO PARANÁ - BRASIL}

representa um raio de 79 células (1580 metros). Para o IPT de raio mais detalhado, tendo como referência a área de $10-1 \mathrm{~km}^{2}$, o raio adotado foi de 8 células (160 metros).
A declividade, atributo topográfico utilizado para distinguir as classes de declive constante representadas pelo IPT (áreas planas e vertentes intermediárias), foi calculada a partir das variáveis direcionais de Horn (1981).

Quadro 02 - Classificação taxonômica de Tricart (1965)

\begin{tabular}{|c|c|c|c|c|c|}
\hline Ordem & $\begin{array}{c}\begin{array}{c}\text { Unidade } \\
\text { de }\end{array} \\
\text { superficie } \\
\text { em } \mathbf{k m}^{2}\end{array}$ & $\begin{array}{c}\text { Características das } \\
\text { unidades e } \\
\text { exemplos }\end{array}$ & $\begin{array}{l}\text { Unidades climáticas } \\
\text { correspondentes }\end{array}$ & $\begin{array}{l}\text { Mecanismos genéticos } \\
\text { comandando o relevo }\end{array}$ & $\begin{array}{c}\text { Ordem de } \\
\text { grandeza de } \\
\text { permanência } \\
\text { temporal }\end{array}$ \\
\hline $\mathbf{I}$ & $10^{7}$ & $\begin{array}{l}\text { Continentes, bacias } \\
\text { oceânicas }\end{array}$ & $\begin{array}{l}\text { Grandes conjuntos zonais, } \\
\text { comandados por fatores } \\
\text { astronômicos }\end{array}$ & $\begin{array}{l}\text { Diferenciação da crosta } \\
\text { terrestre, SIAL e SIMA }\end{array}$ & $10^{9}$ anos \\
\hline II & $10^{6}$ & $\begin{array}{l}\text { Grandes conjuntos } \\
\text { estruturais }\end{array}$ & $\begin{array}{l}\text { Grandes tipos de clima } \\
\text { (interferência de influências } \\
\text { geográficas com fatores } \\
\text { astronômicos) }\end{array}$ & $\begin{array}{c}\text { Movimento da crosta } \\
\text { terrestre como a formação } \\
\text { dos geosinclinais. } \\
\text { Influências climáticas sobre } \\
\text { a dissecação }\end{array}$ & $10^{8}$ anos \\
\hline III & $10^{4}$ & $\begin{array}{l}\text { Grandes unidades } \\
\text { estruturais }\end{array}$ & $\begin{array}{l}\text { Nuances em tipos de } \\
\text { climas, mas sem grande } \\
\text { importância para a } \\
\text { dissecação }\end{array}$ & $\begin{array}{l}\text { Unidades tectônicas ligadas } \\
\text { à Paleogeografia. } \\
\text { Velocidade da dissecação } \\
\text { influenciada pela litologia }\end{array}$ & $10^{7}$ anos \\
\hline IV & 10 & $\begin{array}{l}\text { Unidades tectônicas } \\
\text { elementares (maciços } \\
\text { montanhosos, horsts, } \\
\text { fossas etc.) }\end{array}$ & $\begin{array}{c}\text { Climas regionais de } \\
\text { influência geográfica } \\
\text { sobretudo nas regiões } \\
\text { montanhosas }\end{array}$ & $\begin{array}{l}\text { Influência predominante da } \\
\text { tectônica, secundária da } \\
\text { litologia }\end{array}$ & \\
\hline \multicolumn{6}{|c|}{ Soleira de Compensação Isostática } \\
\hline V & 10 & $\begin{array}{l}\text { Acidentes tectônicos } \\
\text { (anticlinas, sinclinal, } \\
\text { mont etc.) }\end{array}$ & $\begin{array}{l}\text { Climas locais influenciados } \\
\text { pela disposição do relevo }\end{array}$ & $\begin{array}{l}\text { Predominância da litologia e } \\
\text { tectostatica. Influências } \\
\text { estruturais clássicas }\end{array}$ & $\begin{array}{c}10^{7} \text { anos a } \\
10^{6} \text { anos }\end{array}$ \\
\hline VI & $10^{-2}$ & $\begin{array}{l}\text { Formas de relevo } \\
\text { (crista, terraço, } \\
\text { moraina, cone de } \\
\text { dejeção etc.) }\end{array}$ & $\begin{array}{l}\text { Mesoclima diretamente } \\
\text { ligado a forma }\end{array}$ & $\begin{array}{l}\text { Predominância do fator } \\
\text { morfodinâmico influenciado } \\
\text { pela litologia }\end{array}$ & $10^{4}$ anos \\
\hline VII & $10^{-6}$ & $\begin{array}{c}\text { Microformas (lentes } \\
\text { de solifluxão, solos } \\
\text { poligonais, ravinas } \\
\text { etc.) }\end{array}$ & $\begin{array}{l}\text { Microclima diretamente } \\
\text { ligado à forma por } \\
\text { autocatalise }\end{array}$ & $\begin{array}{l}\text { Microclima diretamente } \\
\text { ligado à forma por } \\
\text { autocatalise (ex.: lapiás) }\end{array}$ & $10^{2}$ anos \\
\hline VII & $10^{-8}$ & $\begin{array}{l}\text { Feições microscópicas } \\
\text { (detalhe de corrosão, } \\
\text { de polimento etc.) }\end{array}$ & Microambiente & $\begin{array}{l}\text { Influência da dinâmica e da } \\
\text { textura da rocha }\end{array}$ & \\
\hline
\end{tabular}

\section{VERIFICAÇÃO DA CLASSIFICAÇÃO DO RELEVO}

Foi realizada uma análise da distribuição das classes do relevo para cada uma das 50 subunidades morfoesculturais identificadas pelo mapeamento geomorfológico do Paraná (SANTOS et al., 2006), que constitui uma abordagem da distribuição das classes de relevo em compartimentos em escala regional.

Posteriormente, a avaliação da fidedignidade das classes de relevo identificadas foi realizada por meio de controle de campo em cinco recortes de áreas amostrais distribuídos no território paranaense. Durante as campanhas de campo foram coletadas fotos georrefenciadas representativas do relevo, obtidas no nível do solo e também em voos realizados com um drone, modelo Phantom 3.
Nas áreas amostrais eleitas para serem discutidas ao longo do trabalho foi estabelecida a dimensão de $10 \mathrm{~km}$ de lado no sentido N-S e E-W. A análise desses recortes permitiu a representação em maior detalhe e possibilitou avaliar a representatividade das classes de relevo obtidas do IPT em escala local.

\section{RESULTADOS E DISCUSSÕES}

A classificação geomorfométrica automatizada das 10 formas de relevo que ocorrem no cenário paranaense (Figura 2) referese a: 1) Fundos de vales com forte incisão da drenagem e cânions; 2) Vales rasos e áreas de drenagem situadas no terço médio das vertentes; 3) cabeceiras de drenagens; 4) áreas situadas nos terços inferiores das vertentes ou vales abertos e em forma de $U$; 5) áreas planas; 6) áreas situadas nas posições intermediárias das vertentes; 7) 


\section{ÍNDICE DE POSIÇÃO TOPOGRÁFICA (IPT) PARA CLASSIFICAÇÃO GEOMORFOMÉTRICA DAS FORMAS DE RELEVO NO ESTADO DO PARANÁ - BRASIL}

áreas situadas nas posições superiores das vertentes, patamares superiores ou mesas; 8) interflúvios secundários ou situados nas porções intermediárias das vertentes; 9) topos rebaixados, interflúvios, cristas intermediárias ou morros em áreas planas; 10) interflúvios elevados ou na forma de cristas elevadas e topos elevados.

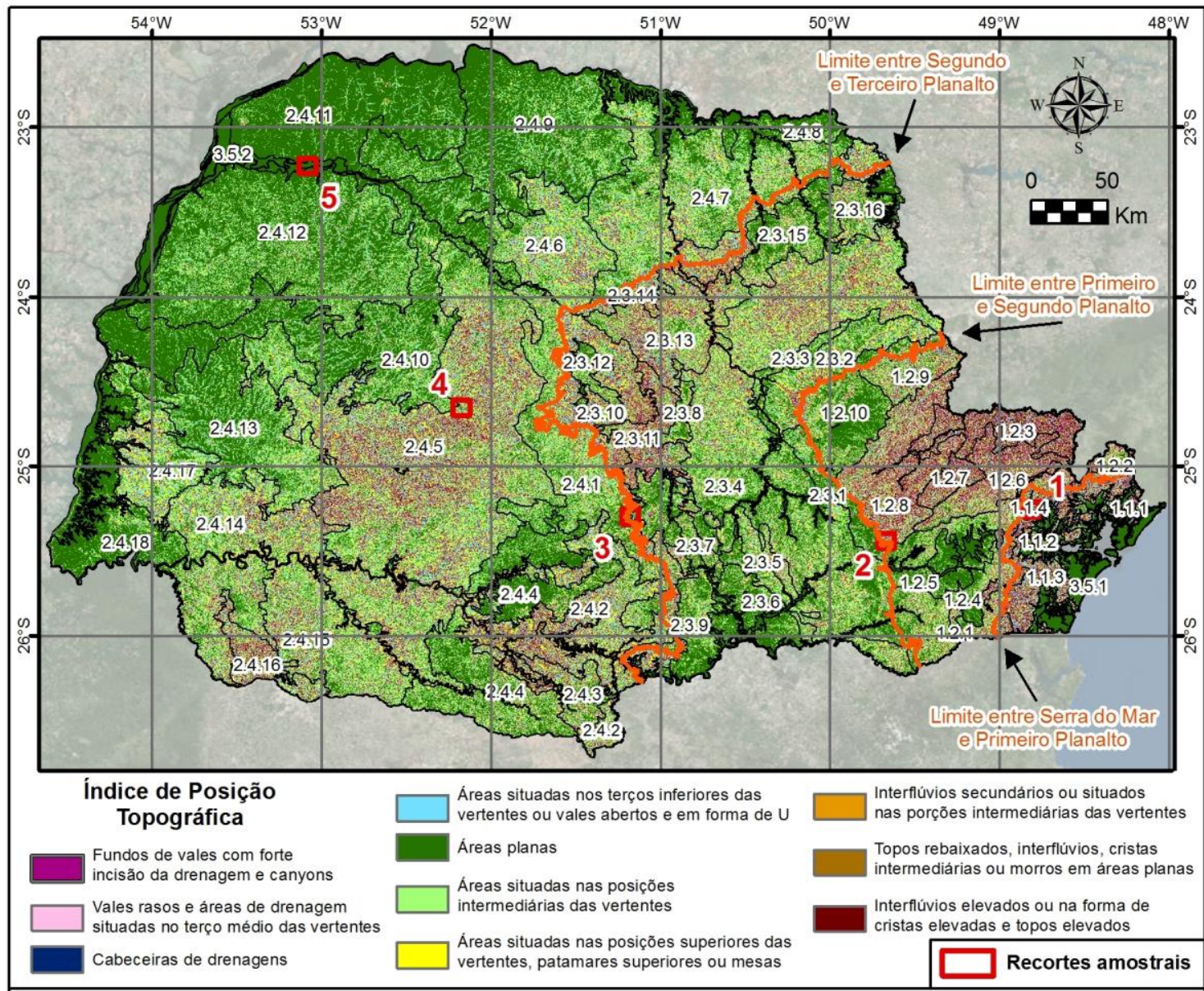

Subunidades morfoesculturais do Mapeamento Geomorfológico do Estado do Paraná (SANTOS et al., 2006)

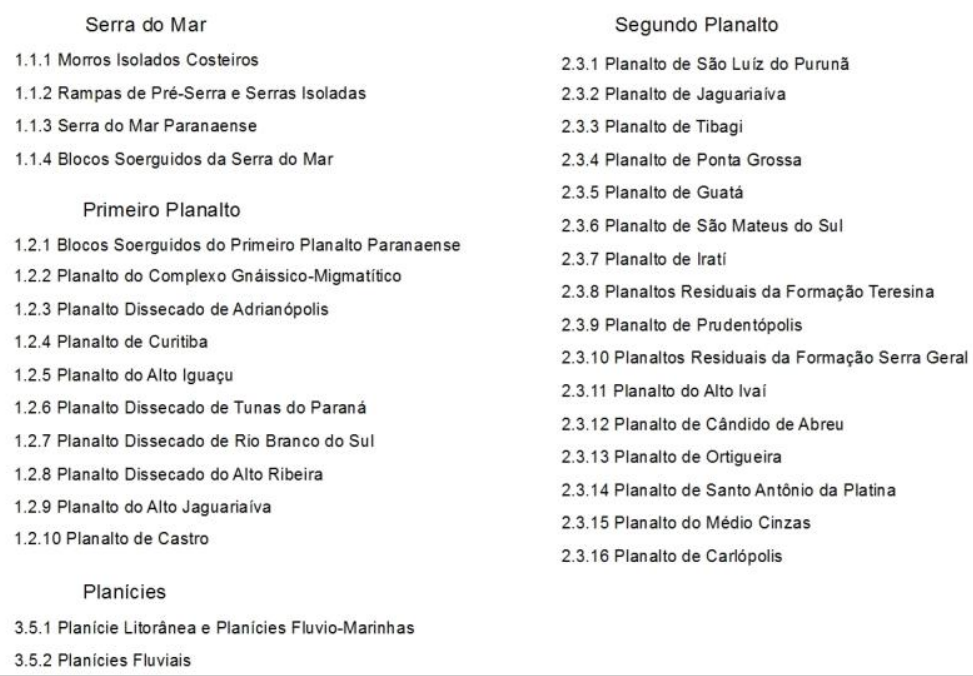

Segundo Planalto

2.3.1 Planalto de São Luiz do Purunã

2.3.2 Planalto de Jaguariaiva

2.3.3 Planalto de Tibagi

2.3.4 Planalto de Ponta Grossa

2.3.5 Planalto de Guatá

2.3.6 Planalto de São Mateus do Sul

2.3.7 Planalto de Irati

2.3.8 Planaltos Residuais da Formação Teresina

2.3.9 Planalto de Prudentópolis

2.3.10 Planaltos Residuais da Formação Serra Geral

2.3.11 Planalto do Alto Ivai

2.3.12 Planalto de Cândido de Abreu

2.3.13 Planalto de Ortigueira

2.3.14 Planalto de Santo Antônio da Platina

2.3.15 Planalto do Médio Cinzas

2.3.16 Planalto de Carlópolis

Terceiro Planalto

$$
\begin{aligned}
& \text { 2.4.1 Planalto Pitanga/lvaiporã } \\
& \text { 2.4.2 Planalto do Foz do Areia } \\
& \text { 2.4.3 Planalto de Clevelândia } \\
& \text { 2.4.4 Planalto de Palmas/Guarapuava } \\
& \text { 2.4.5 Planalto do Alto/Médio Piquiri } \\
& \text { 2.4.6 Planalto de Apucarana } \\
& \text { 2.4.7 Planalto de Londrina } \\
& \text { 2.4.8 Planalto do Médio Paranapanema } \\
& \text { 2.4.9 Planalto de Maringá } \\
& \text { 2.4.10 Planalto de Campo Mourão } \\
& \text { 2.4.11 Planalto de Paranavaí } \\
& \text { 2.4.12 Planalto de Umuarama } \\
& \text { 2.4.13 Planalto de Cascavel } \\
& \text { 2.4.14 Planalto do Baixo Iguaçu } \\
& \text { 2.4.15 Planalto de Francisco Beltrão } \\
& \text { 2.4.16 Planalto do Alto Capanema } \\
& \text { 2.4.17 Planalto do São Francisco } \\
& \text { 2.4.18 Planalto de Foz do Iguaçu }
\end{aligned}
$$

Figura 02 - Classificação geomorfométrica das formas de relevo distribuídos no Paraná sobre as subunidades morfoesculturais do mapeamento geomorfológico na escala 1:250.000. 


\section{SILVEIRA,C.T. E SILVEIRA, R.M.P. \\ ÍNDICE DE POSIÇÃO TOPOGRÁFICA (IPT) PARA CLASSIFICAÇÃO GEOMORFOMÉTRICA DAS FORMAS DE RELEVO NO ESTADO DO PARANÁ - BRASIL}

Em escala regional é possível verificar sobre as subunidades morfoesculturais de (SANTOS et al., 2006) que as dez classes do IPT configuram distintos arranjos espaciais, expressando diferentes padrões de agrupamento de formas de relevo no Paraná (Figura 2), cujos percentuais são demonstrados na Tabela 1 . Avaliando diferentes valores de representação em cada uma das subunidades, corrobora-se a afirmativa de que o arranjo das classes de IPT propicia a distinção e identificação de unidades com padrão similar de relevo.

Tabela 01 - Distribuição em porcentagem das classes de IPT sobre as subunidades morfoesculturais.

\begin{tabular}{|c|c|c|c|c|c|c|c|c|c|c|c|}
\hline & \multirow{2}{*}{ SUBUNIDADE MORFOESCULTURAL } & \multicolumn{10}{|c|}{ CLASSES DO IPT (EM PORCENTAGEM RELATIVA DE ÁREA) } \\
\hline & & 1 & 2 & 3 & 4 & 5 & 6 & 7 & 8 & 9 & 10 \\
\hline \multirow{4}{*}{ Serra do Mar } & Morros Isolados Costeiros & 11.85 & 10.78 & 7.54 & 11.61 & 1.02 & 13.75 & 13.63 & 2.41 & 7.75 & 19.67 \\
\hline & Rampas de Pré-Serra e Serras Isoladas & 4.34 & 13.69 & 0.85 & 10.85 & 24.19 & 24.39 & 2.80 & 0.66 & 10.41 & 7.82 \\
\hline & Serra do Mar Paranaense & 15.73 & 8.90 & 5.75 & 16.08 & 0.37 & 13.53 & 10.79 & 4.63 & 8.37 & 15.85 \\
\hline & Blocos Soerguidos da Serra do Mar & 13.70 & 8.76 & 7.86 & 11.03 & 0.23 & 11.94 & 14.66 & 3.72 & 7.29 & 20.81 \\
\hline \multirow{10}{*}{$\begin{array}{c}\text { Primeiro } \\
\text { Planalto } \\
\text { Paranaense }\end{array}$} & Blocos Soerguidos do Primeiro Planalto Paranaense & 9.29 & 12.26 & 3.43 & 8.47 & 7.38 & 25.86 & 8.53 & 0.96 & 11.51 & 12.31 \\
\hline & Planalto de Castro & 1.76 & 5.09 & 0.21 & 3.21 & 55.58 & 24.53 & 3.06 & 0.14 & 4.53 & 1.90 \\
\hline & Planalto do Complexo Gnáissico-Migmatítico & 8.55 & 19.26 & 1.32 & 4.82 & 8.44 & 25.95 & 3.68 & 1.12 & 17.49 & 9.36 \\
\hline & Planalto Dissecado de Adrianópolis & 18.92 & 10.99 & 6.07 & 10.02 & 0.15 & 9.32 & 8.90 & 5.47 & 10.54 & 19.61 \\
\hline & Planalto de Curitiba & 2.79 & 12.96 & 0.13 & 2.43 & 28.92 & 35.01 & 1.88 & 0.19 & 12.61 & 3.09 \\
\hline & Planalto do Alto Iguaçu & 0.01 & 2.83 & 0.00 & 0.03 & 73.40 & 20.18 & 0.20 & 0.00 & 3.16 & 0.18 \\
\hline & Planalto Dissecado de Tunas do Paraná & 14.00 & 16.11 & 2.14 & 6.26 & 3.60 & 19.72 & 5.48 & 1.86 & 16.49 & 14.34 \\
\hline & Planalto Dissecado de Rio Branco do Sul & 18.80 & 13.56 & 3.02 & 7.51 & 0.51 & 13.31 & 6.27 & 3.30 & 15.32 & 18.38 \\
\hline & Planalto Dissecado do Alto Ribeira & 14.31 & 16.06 & 1.41 & 6.77 & 2.69 & 20.58 & 5.58 & 1.47 & 17.94 & 13.20 \\
\hline & Planalto do Alto Jaguariaiva & 7.22 & 13.59 & 0.68 & 8.14 & 12.71 & 31.45 & 5.00 & 0.70 & 14.32 & 6.19 \\
\hline \multirow{16}{*}{$\begin{array}{c}\text { Segundo } \\
\text { Planalto } \\
\text { Paranaense }\end{array}$} & Planalto de São Luiz do Purunã & 3.25 & 3.76 & 0.27 & 4.34 & 46.59 & 25.43 & 10.72 & 0.22 & 3.39 & 2.03 \\
\hline & Planaltos Residuais da Formação Serra Geral & 11.52 & 9.01 & 1.92 & 14.53 & 4.75 & 23.51 & 12.39 & 2.29 & 10.51 & 9.55 \\
\hline & Planalto do Alto Ivaí & 13.52 & 13.13 & 1.18 & 10.66 & 5.37 & 21.82 & 6.08 & 1.74 & 16.74 & 9.75 \\
\hline & Planalto de Cândido de Abreu & 3.24 & 7.74 & 0.12 & 7.16 & 33.68 & 36.49 & 2.91 & 0.20 & 6.93 & 1.53 \\
\hline & Planalto de Ortigueira & 8.98 & 10.63 & 1.03 & 9.24 & 10.41 & 31.89 & 8.11 & 0.80 & 11.12 & 7.79 \\
\hline & Planalto de Santo Antônio da Platina & 10.84 & 8.17 & 1.94 & 13.91 & 7.36 & 23.40 & 13.37 & 1.97 & 9.21 & 9.83 \\
\hline & Planalto do Médio Cinzas & 1.31 & 5.83 & 0.08 & 2.70 & 51.83 & 28.69 & 3.02 & 0.04 & 4.95 & 1.55 \\
\hline & Planalto de Carlópolis & 3.16 & 8.39 & 0.53 & 5.01 & 31.48 & 32.03 & 7.98 & 0.12 & 7.19 & 4.11 \\
\hline & Planalto de Jaguariaiva & 6.25 & 4.80 & 0.25 & 8.24 & 26.75 & 33.79 & 11.87 & 0.74 & 4.70 & 2.61 \\
\hline & Planalto de Tibagi & 2.39 & 3.55 & 0.01 & 4.94 & 45.46 & 35.77 & 5.30 & 0.04 & 2.18 & 0.35 \\
\hline & Planalto de Ponta Grossa & 5.08 & 7.38 & 0.19 & 6.30 & 26.20 & 35.86 & 8.49 & 0.24 & 7.10 & 3.16 \\
\hline & Planalto de Guatá & 3.78 & 9.30 & 0.04 & 4.59 & 23.56 & 40.00 & 7.62 & 0.06 & 7.97 & 3.08 \\
\hline & Planalto de São Mateus do Sul & 0.15 & 2.31 & 0.00 & 0.49 & 70.77 & 22.07 & 1.41 & 0.00 & 2.16 & 0.64 \\
\hline & Planalto de Irati & 2.30 & 9.68 & 0.17 & 3.37 & 33.42 & 33.50 & 4.84 & 0.03 & 8.11 & 4.59 \\
\hline & Planaltos Residuais da Formação Teresina & 3.18 & 7.85 & 1.23 & 3.76 & 28.54 & 29.26 & 13.18 & 0.20 & 5.72 & 7.07 \\
\hline & Planalto de Prudentópolis & 1.43 & 5.33 & 0.22 & 2.53 & 50.50 & 28.75 & 4.01 & 0.10 & 4.73 & 2.40 \\
\hline \multirow{18}{*}{$\begin{array}{c}\text { Terceiro } \\
\text { Planalto } \\
\text { Paranaense }\end{array}$} & Planalto de Pitanga/lvaiporã & 3.62 & 5.87 & 0.34 & 6.26 & 27.84 & 37.88 & 9.77 & 0.16 & 5.05 & 3.21 \\
\hline & Planalto de Campo Mourão & 1.44 & 1.23 & 0.00 & 4.02 & 68.18 & 22.10 & 2.27 & 0.01 & 0.62 & 0.13 \\
\hline & Planalto de Paranavaí & 0.37 & 0.38 & 0.00 & 1.68 & 87.71 & 9.20 & 0.41 & 0.00 & 0.22 & 0.04 \\
\hline & Planalto de Umuarama & 1.30 & 1.74 & 0.00 & 3.55 & 62.29 & 28.60 & 1.81 & 0.00 & 0.64 & 0.06 \\
\hline & Planalto de Cascavel & 1.90 & 1.54 & 0.02 & 6.50 & 54.65 & 28.75 & 4.93 & 0.06 & 1.12 & 0.53 \\
\hline & Planalto do Baixo Iguaçu & 6.02 & 6.46 & 0.35 & 10.86 & 15.74 & 37.02 & 10.93 & 0.29 & 6.19 & 6.14 \\
\hline & Planalto de Francisco Beltrão & 5.48 & 7.79 & 0.27 & 8.93 & 15.46 & 40.44 & 8.45 & 0.16 & 7.46 & 5.56 \\
\hline & Planalto do Alto Capanema & 11.92 & 8.79 & 1.39 & 11.73 & 3.37 & 26.02 & 12.62 & 1.71 & 9.83 & 12.62 \\
\hline & Planalto do São Francisco & 3.69 & 3.82 & 0.25 & 13.90 & 21.58 & 35.11 & 14.42 & 0.18 & 3.37 & 3.67 \\
\hline & Planalto de Foz do Iguaçu & 0.32 & 0.65 & 0.01 & 2.15 & 80.26 & 14.34 & 1.49 & 0.00 & 0.43 & 0.35 \\
\hline & Planalto do Foz do Areia & 9.66 & 6.71 & 1.40 & 16.14 & 6.95 & 26.17 & 15.22 & 1.51 & 6.89 & 9.35 \\
\hline & Planalto de Clevelândia & 6.93 & 9.15 & 1.17 & 9.08 & 17.62 & 28.46 & 10.07 & 0.87 & 8.42 & 8.22 \\
\hline & Planalto de Palmas/Guarapuava & 1.28 & 4.09 & 0.07 & 2.46 & 54.57 & 28.00 & 4.34 & 0.09 & 3.75 & 1.36 \\
\hline & Planalto do Alto/Médio Piquiri & 8.74 & 8.28 & 0.58 & 10.89 & 10.28 & 33.50 & 10.61 & 0.57 & 8.44 & 8.11 \\
\hline & Planalto de Apucarana & 4.80 & 5.69 & 0.25 & 11.44 & 19.54 & 38.80 & 10.00 & 0.13 & 4.71 & 4.64 \\
\hline & Planalto de Londrina & 3.39 & 4.55 & 0.11 & 8.34 & 31.66 & 37.28 & 8.62 & 0.07 & 3.47 & 2.50 \\
\hline & Planalto do Médio Paranapanema & 0.35 & 1.08 & 0.01 & 1.85 & 77.31 & 17.28 & 1.31 & 0.00 & 0.52 & 0.28 \\
\hline & Planalto de Maringá & 1.08 & 0.86 & 0.00 & 4.32 & 70.10 & 21.16 & 1.98 & 0.00 & 0.44 & 0.07 \\
\hline \multirow{2}{*}{ Planicies } & Planicie Litorânea e Planicies Fluvio-Marinhas & 2.16 & 1.47 & 0.02 & 10.81 & 79.39 & 3.64 & 0.09 & 0.43 & 1.60 & 0.41 \\
\hline & Planícies Fluviais & 0.65 & 0.55 & 0.01 & 3.49 & 90.91 & 3.60 & 0.11 & 0.05 & 0.52 & 0.11 \\
\hline
\end{tabular}




\section{SILVEIRA,C.T. E SILVEIRA, R.M.P. \\ ÍNDICE DE POSIÇÃO TOPOGRÁFICA (IPT) PARA CLASSIFICAÇÃO GEOMORFOMÉTRICA DAS FORMAS DE RELEVO NO ESTADO DO PARANÁ - BRASIL}

Legenda das classes do IPT: 1) Fundos de vales com forte incisão da drenagem e cânions; 2) Vales rasos e áreas de drenagem situadas no terço médio das vertentes; 3 ) cabeceiras de drenagens; 4) áreas situadas nos terços inferiores das vertentes ou vales abertos e em forma de $U$; 5 ) áreas planas; 6) áreas situadas nas posições intermediárias das vertentes; 7) áreas situadas nas posições superiores das vertentes, patamares superiores ou mesas; 8) interflúvios secundários ou situados nas porções intermediárias das vertentes; 9) topos rebaixados, interflúvios, cristas intermediárias ou morros em áreas planas; 10) interflúvios elevados ou na forma de cristas elevadas e topos elevados.

Nas subunidades morfoesculturais da Serra do Mar se evidencia a baixa representatividade das classes de IPT 5 e 8 , sendo a primeira relativa as áreas planas e a segunda aos interflúvios situados nas porções intermediárias das vertentes. Embora pouco evidentes nesta subunidade, as áreas planas são recorrentes naquela denominada Rampas de PréSerra e Serras isoladas, já que constituem a transição das serras com as planícies; enquanto os interflúvios no relevo serrano prevalecem nas posições mais elevadas, sendo representados pelas classes 9 e 10 (Figura 3). Neste sentido, as subunidades da Serra do Mar são caracterizadas por relevo dissecado com ocorrência de fundos de vales dotados de forte incisão da drenagem; interflúvios elevados ou em forma de cristas elevadas e topos elevados; cristas e interflúvios intermediários, com vertentes extensas que favorecem sua compartimentação, nos terços inferior, intermediário e superior das vertentes.

Nas dez subunidades morfoesculturais do Primeiro Planalto Paranaense, a distinção mais evidente refere-se a áreas planas nos Planaltos de Curitiba, Alto Iguaçu e Castro (respectivamente: $1.2 .4,1.2 .5$ e 1.2.10), ilustrada no mapa da figura 2 pelo predomínio da cor verde escuro nessas subunidades, pois essas possuem extensas planícies fluviais. A exceção está nos planaltos dissecados desenvolvidos sobre o Grupo Açungui, cuja influência estrutural de falhas, fraturas e denudação diferencial em litotipos com distintas resistências, associado ao seu nível de base, confere um relevo com ampla dissecação, onde prevalecem as classes 9 e 10, que configuram cristas e interflúvios elevados ou secundários com orientação predominante para NW ou NE, à mercê do controle estrutural geológico regional, também as classes 1 e 2 que representam vales com forte incisão da drenagem e áreas de drenagem situadas no terço médio de vertente. $O$ padrão predominante das formas de relevo nos planaltos dissecados do Primeiro Planalto (subunidades 1.2.3, 1.2.6, 1.2.7 e 1.2.8) se assemelham às encontradas na Serra do Mar (Figura 3).

O segundo Planalto Paranaense é composto por 16 subunidades, das quais doze apresentam maior representatividade para as classes IPT 5 e 6 . A primeira expressa áreas planas, enquanto a segunda terços intermediário das vertentes, secundariamente a classe 7 e 4 estão presentes, identificando, respectivamente, patamares superiores/porção superior das vertentes e terço inferior das mesmas. Caso de exceção é observado nas subunidades Planalto Residuais da Formação Serra Geral, Alto Ivaí, Ortigueira e Santo Antônio da Platina, respectivamente: 2.3.10, 2.3.11, 2.3.13 e 2.3.14. A distinção da distribuição das classes do IPT nesse conjunto de subunidade é bastante perceptível no mapa representado na Figura 2, nessas subunidades as áreas planas não são as mais representativas e as classes 1, 2, 4, 6, 9 e 10 tem maior expressão em relação às demais (Figura 3).

O Terceiro Planalto Paranaense é dividido em 18 subunidades, sendo que em oito delas (Planaltos de Campo Mourão, Paranavaí, Umuarama, Cascavel, Foz do Iguaçu, Palmas/Guarapuava, Médio Paranapanema e Maringá), há grande representatividade da classe de IPT 5 (áreas planas), com reduzida expressão das demais classes. No mapa da figura 2 é possível identificar similaridade entre as subunidades definidas por Santos et al. (2006) com o arranjo das formas de relevo classificadas por meio do IPT, sendo perceptível o predomínio 


\section{ÍNDICE DE POSIÇÃO TOPOGRÁFICA (IPT) PARA CLASSIFICAÇÃO GEOMORFOMÉTRICA DAS FORMAS DE RELEVO NO ESTADO DO PARANÁ - BRASIL}

da cor verde escuro no interior dessas subunidades, que reforça a potencialidade de uso do IPT para a identificação desses padrões. Outras seis subunidades (Planaltos Pitanga/Ivorá, Apucarana, Londrina Baixo Iguaçu, Francisco Beltrão e São Francisco) apresentam maior diversidade de formas de relevo em relação às anteriores. Apesar do predomínio da classe IPT 6 as demais classes possuem significativa representatividade, exceto as classes 3 e 8 pouco frequentes em todas as subunidades (Figura 3 e tabela 1). No mapa da figura 2 é possível perceber a distinção dessas subunidades por meio da coloração verde claro dos polígonos e verificar a coincidência da delimitação deles com o padrão resultante do IPT. As outras quatro unidades, designadas como Planaltos Foz do Areia, Clevelândia, Alto/Médio Piquiri e Alto Capanema, apresenta padrão de distribuição das classes do IPT distinto das subunidades anteriores, com maior representação das classes 1, 2, 9 e 10 (Figura 3), que conjectura relevo enérgico e caracterizado por vales mais profundos e divisores mais elevados. A representação dessas unidades no mapa da figura 4 revela que seu arranjo de classes de formas de relevo se distingue das demais.

Em tempo, as subunidades Planícies Litorâneas/Flúvio-Marinhas (3.5.1) e Planícies Fluviais (3.5.2), têm o destaque esperado das formas de relevo da classe 5 , visto que nesses ambientes predominam áreas planas. 


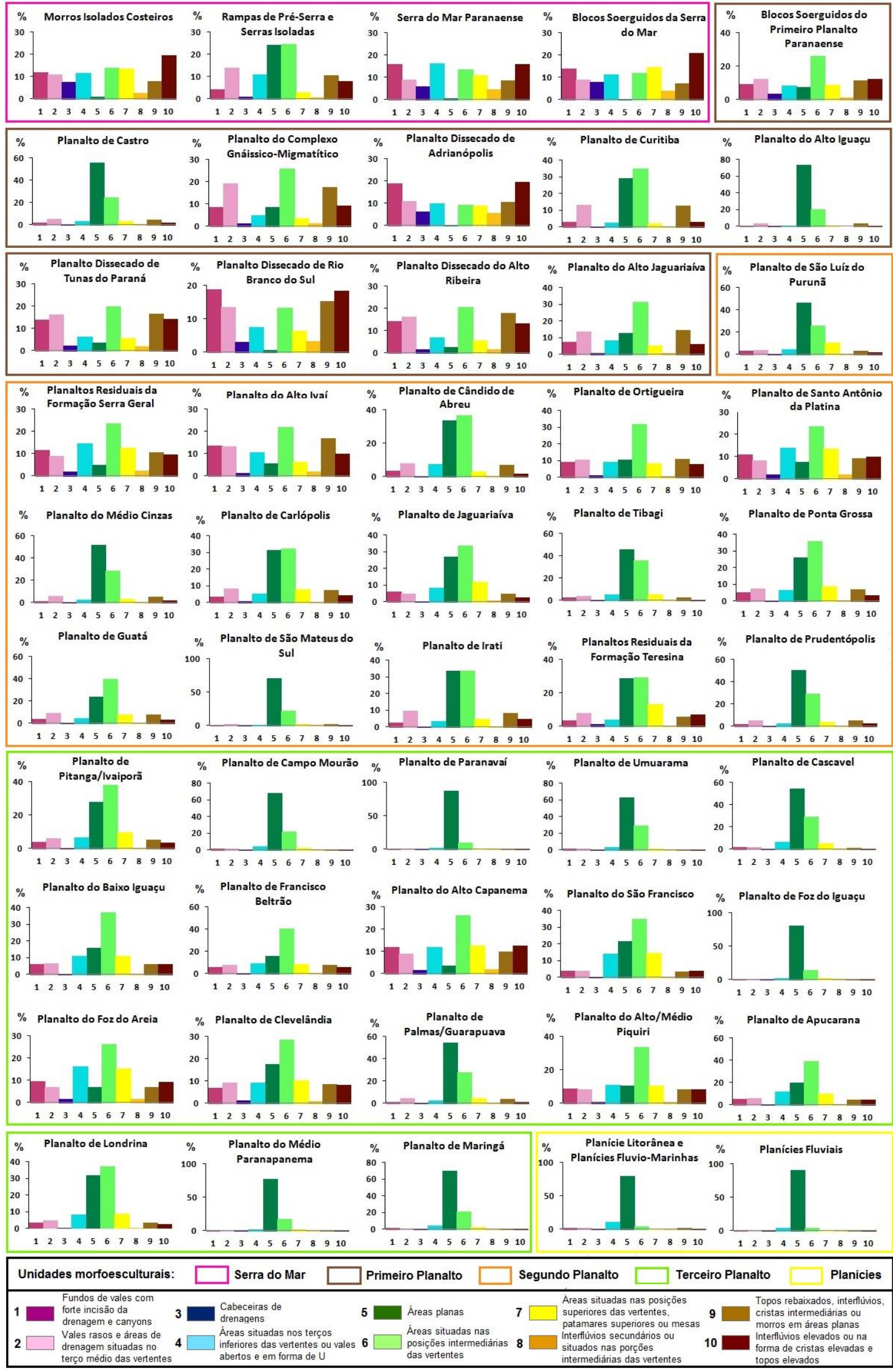




\section{ÍNDICE DE POSIÇÃO TOPOGRÁFICA (IPT) PARA CLASSIFICAÇÃO GEOMORFOMÉTRICA DAS FORMAS DE RELEVO NO ESTADO DO PARANÁ - BRASIL}

Figura 3 - Distribuição das classes do IPT nas unidades e subunidades morfoesculturais.

A seleção dos cinco distintos recortes distribuídos no Paraná, apresentados na figura 2, permitiram a representação em maior detalhe e possibilitaram avaliar a representatividade das unidades de relevo em escala local, contando com reconhecimento e registro fotográfico de campo, complementadas empiricamente, à fundamentação teórica regional.

$$
0 \text { recorte amostral } 1 \text { (figura 4) }
$$
representa o relevo da Serra do Mar - região que apresenta as mais destacadas variações altimétricas do Paraná, cujo compartimento é uma das cinco regiões geográficas naturais do estado identificadas por Maack (1968), tratada como unidade morfoescultural em Santos et al. (2006). Sua evolução tem atribuição poligenética, com contribuição de ciclos erosivos que elaboraram superfícies aplainadas atualmente estão escalonadas na paisagem, conformando as superfícies de erosão/aplainamento identificadas por Ab'Sáber e Bigarella (1961) e Bigarella et al. (1978), por eles designadas de Superfície Purunã (Pd3), Superfície Alto Iguaçu (Pd2) e Superfície Curitiba (Pd1). Também pela influência de eventos tectônicos, dissecação regressiva do front na face oriental e erosão diferencial pela presença de litologia de maior resistência que sustentam elevações de destaque (ALMEIDA; CARNEIRO, 1998). Nascimento et al. (2013) atribuem ainda o condicionamento morfotectônico na evolução do relevo e atividade neotectônica na sua conformação.

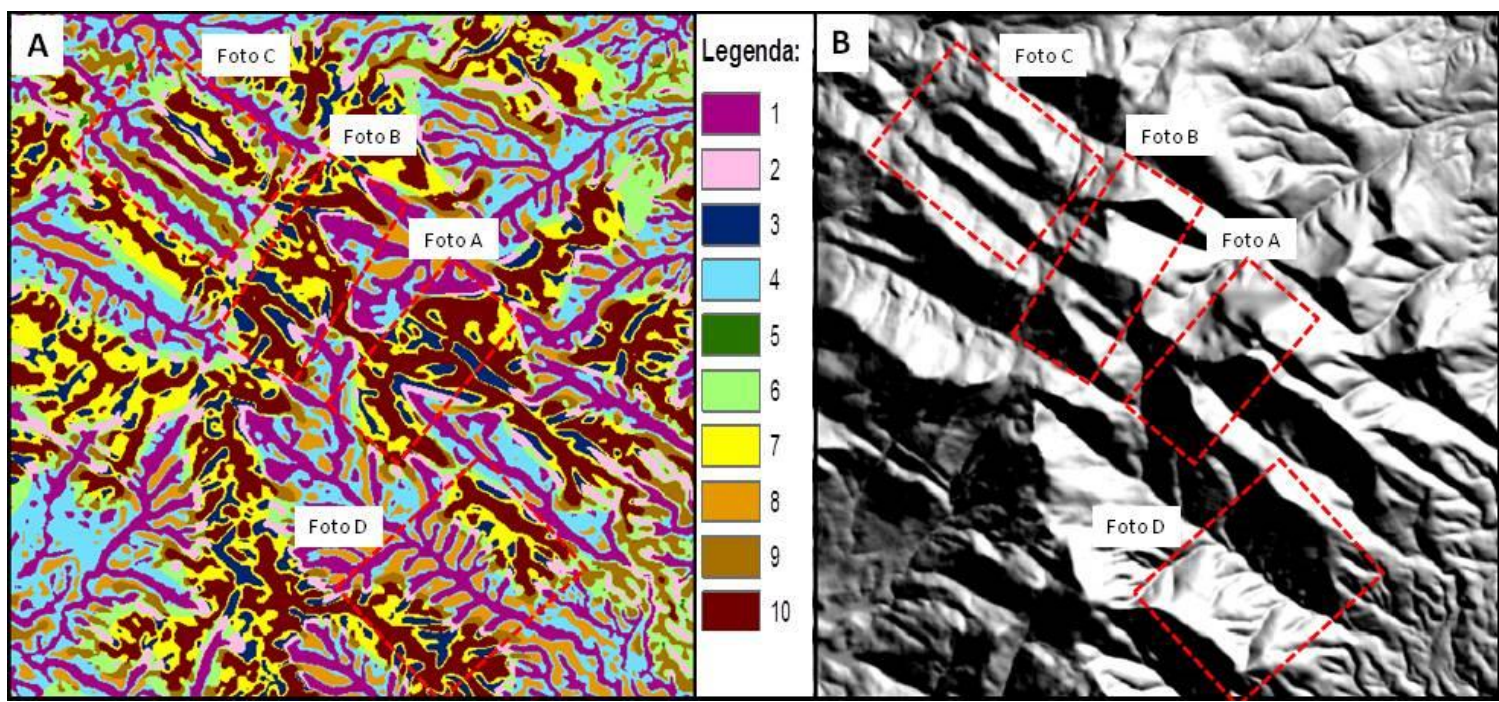

Figura 04 - Recorte da área 1 representa a Serra do Mar Paranaense (Serra do Ibitiraquire): A) formas de relevo obtidas pela classificação automática do IPT; B) relevo sombreado, azimute e ângulo de inclinação solar de 45‥ Os polígonos em cor vermelha situam as fotos de campo A, B, C e D.

Legenda: 1) Fundos de vales com forte incisão da drenagem e cânions; 2) Vales rasos e áreas de drenagem situadas no terço médio das vertentes; 3) cabeceiras de drenagens; 4) áreas situadas nos terços inferiores das vertentes ou vales abertos e em forma de $U$; 5 ) áreas planas; 6 ) áreas situadas nas posições intermediárias das vertentes; 7) áreas situadas nas posições superiores das vertentes, patamares superiores ou mesas; 8) interflúvios secundários ou situados nas porções intermediárias das vertentes; 9) topos rebaixados, interflúvios, cristas intermediárias ou morros em áreas planas; 10) interflúvios elevados ou na forma de cristas elevadas e topos elevados. 


\section{SILVEIRA,C.T. E SILVEIRA, R.M.P. \\ ÍNDICE DE POSIÇÃO TOPOGRÁFICA (IPT) PARA CLASSIFICAÇÃO GEOMORFOMÉTRICA DAS FORMAS DE RELEVO NO ESTADO DO PARANÁ - BRASIL}

A Serra do Mar Paranaense não representa unicamente o degrau entre o litoral e o Primeiro Planalto, mas configura uma serra marginal típica que se eleva com valores altimétricos compreendidos entre 500 e $1.000 \mathrm{~m}$ sobre o nível médio do planalto (MAACK, 1968). Do mesmo modo, sua morfologia não configura exclusivamente uma serra de borda de planalto ou de escarpa, já que possui setores originados por erosão diferencial, onde as maiores elevações, com cimos elevados, são sustentadas por corpos graníticos e litologias metamórficas de alto grau, influenciadas, ainda, por sistemas de falhas, fraturas e diques que, conjuntamente, exercem controle na rede de drenagem e na escarpa do front montanhoso da Serra (SANTOS et al., 2006).

Segundo Almeida e Carneiro (1998) o Cinturão Granitóide Costeiro do Estado do Paraná é que sustenta as maiores elevações da Serra do Mar, cujo relevo é resultado de erosão diferencial regressiva, adaptando-se nesse processo à diversidade de estruturas geológicas e de resistência diferencial das rochas à erosão, bem como à morfotectônica que se manifestou no Planalto Atlântico durante o Paleógeno e o Mioceno.

Regionalmente a Serra do Mar Paranaense configura-se em blocos montanhosos designados, localmente, como Serras da Prata, dos Castelhanos, Canasvieiras, Araraquara, do Engenho, do Cubatão, Ibitiraquire, entre outros.
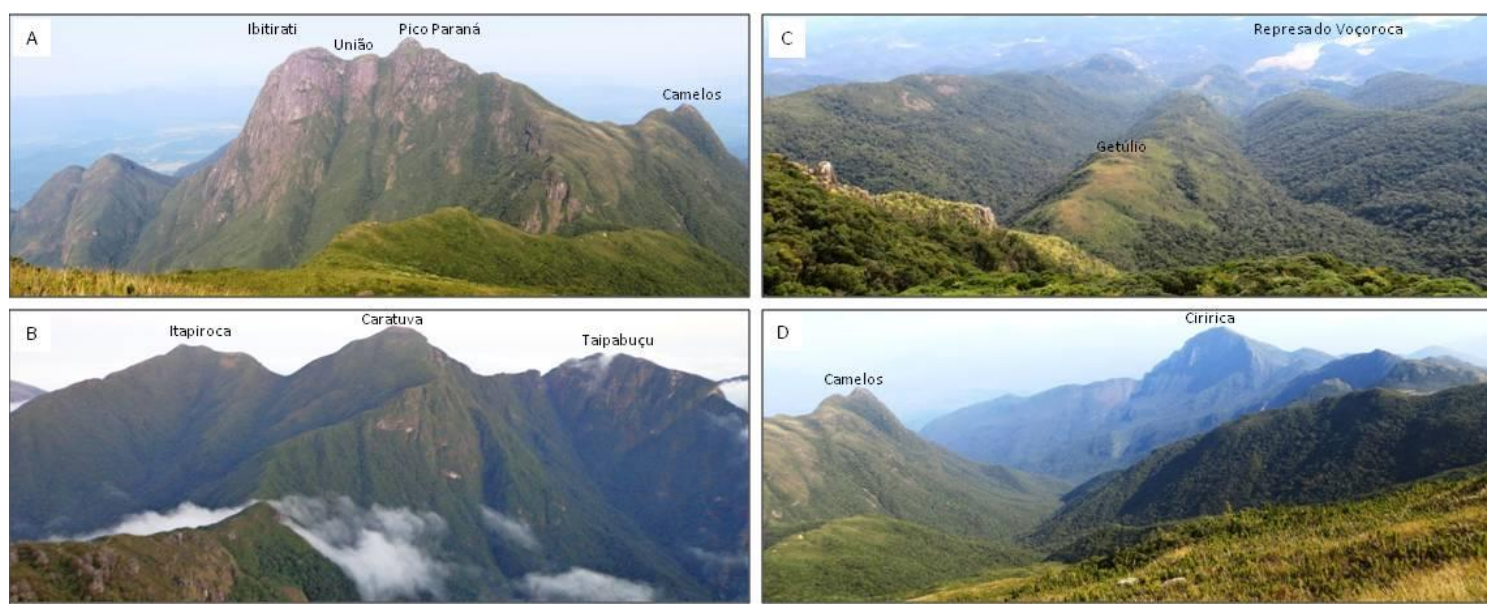

A Serra do Ibitiraquire foi contemplada no recorte amostral 1 , sendo integrante da subunidade morfoescultural Blocos Soerguidos da Serra do Mar (SANTOS et al., 2006). As formas de relevo obtidas na classificação automática do IPT nessa área (figura 4-A) expressam grande representatividade da classe 10 , por sua vez, constituída por interflúvios elevados ou por cristas elevadas e topos elevados. Essas áreas representam as maiores elevações da Serra do Mar, composta por picos que ultrapassam 1700 $\mathrm{m}$ de altitude, destacando-se Pico Paraná (1877m) (figura 5-A), Caratuva (1850m), Itapiroca (1754m), Taipabaçu (1817m) (figura 5-B), Ciririca (1781m) (figura 5-D), Ferraria (1835m) e Morro do Getúlio (1430m) (figura 5-C), (NASCIMENTO et al., 2013). A classe 10 que interliga os interflúvios elevados entre os picos Paraná, União, Ibitirati, Camelos, Ciririca, A2, Ferraria, Taipabuçu, Caratuba, Itapiroca, Cerro Verde, Tucum e Camapuã, apresentada com vista em perfil tridimensional na figura 6 , são consideradas remanescentes da superfície Pd3 por Bigarella et dos corpos graníticos que constituem os altos topográficos representados nas Figuras 5-A, B e D. al. (1978), sustentados pela resistência erosiva 


\section{ÍNDICE DE POSIÇÃO TOPOGRÁFICA (IPT) PARA CLASSIFICAÇÃO GEOMORFOMÉTRICA DAS FORMAS DE RELEVO NO ESTADO DO PARANÁ - BRASIL}

Figura 05 - Fotos ilustrativas do relevo da Serra do Ibitiraquire, Serra do Mar Paranaense.Fonte: Fotos obtidas no nível do solo pelos autores.

Tratando ainda das posições elevadas, as formas de relevo das classes 8 e 9 são respectivamente: 8) interflúvios secundários ou situados nas porções intermediárias das vertentes e 9) topos rebaixados, interflúvios, cristas intermediárias ou morros em áreas planas (Figura 6-A). Em síntese, constituem áreas de cumeada e topos inferiores que estariam associados à superfície Pd2 e/ou Pd1 (BIGARELLA et al., ibid.); e, neste sentido, a classificação das cristas, interflúvios e topos mediante o IPT foi bem sucedida - suas distinções morfológicas são separadas nas classes 10, 9 e 8.

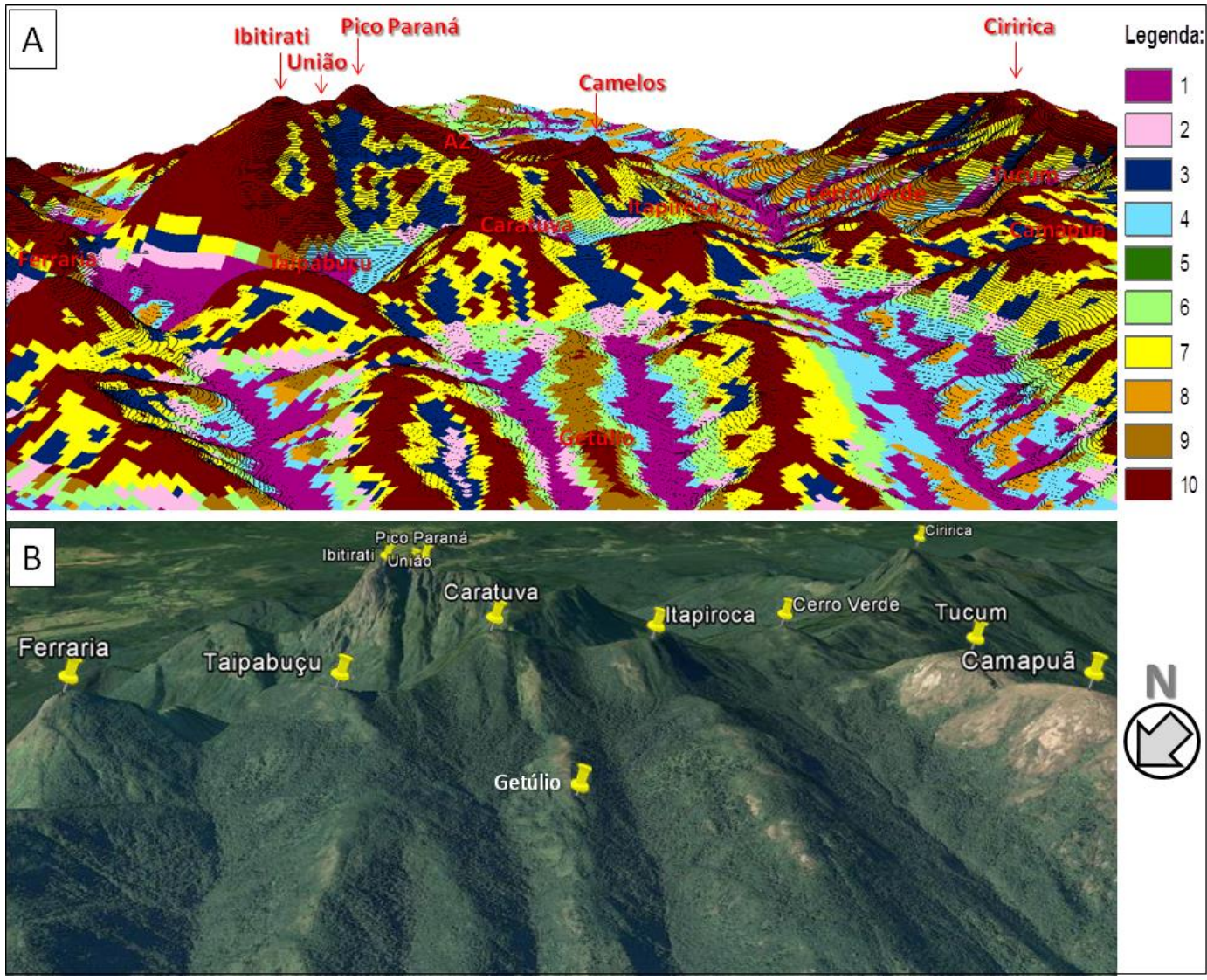

Figura 06 - Ilustração tridimensional da Serra do Ibitiraquire: A) formas de relevo obtidas na classificação do IPT; B) Imagem de satélite obtida do Google Earth com exagero vertical de 2x.

A classe IPT 1, que representa os fundos de vales com forte incisão da drenagem e cânions, apresenta grande representatividade na região serrana. Essas áreas constituem os talvegues e fundos de vale dos cursos de drenagem principais, controlados por falhas e fraturas, algumas com preenchimento de diques associados ao Arco de Ponta Grossa. Os rios principais encontram-se preferencialmente encaixados em diques, com direção noroeste (NW), paralelos às rochas encaixantes de maior resistência denudacional que constituem os interflúvios; secundariamente essa classe apresenta direção preferencial para nordeste (NE), seguindo linhas de falhas e fraturas. Essas constatações podem ser verificadas na classificação do IPT da figura 4-A, visualizando os lineamentos no relevo sombreado da área da figura 4-B, no paralelismo de fundo de vale e interflúvio da figura 5-C e em primeiro plano na figura 6-A. 


\section{SILVEIRA,C.T. E SILVEIRA, R.M.P. \\ ÍNDICE DE POSIÇÃO TOPOGRÁFICA (IPT) PARA CLASSIFICAÇÃO GEOMORFOMÉTRICA DAS FORMAS DE RELEVO NO ESTADO DO PARANÁ - BRASIL}

De modo menos representativo os interflúvios são expressos pelas classes 2, que correspondem a vales rasos e áreas de drenagem situadas no terço médio das vertentes; e 3, relativa às cabeceiras de drenagem. Essas classes também apresentam controle estrutural de falhas e diques, porém, ocupam posições altimétricas superiores, constituindo a rede de drenagem de ordem inferior. Nas figuras 5-A e 6A, entre os picos Paraná e União, União e Ibitirati, os vales declivosos situados em posições elevadas com as nascentes são coincidentes com corpos de diques do Arco de Ponta Grossa. Assim, a classificação automática das áreas, associadas aos fundos de vales e nascentes, demonstraram relação fidedigna com as formas de relevo verificadas em campo na área de estudo.

As classes do IPT 4, 6 e 7 na área 1, representam formas de relevo associadas aos terços inferiores, posições intermediárias e terços superiores das vertentes, respectivamente, que expressam distintos segmentos das vertentes na transição entre os interflúvios e fundos de vale na região da Serra do Mar. A classificação apresentou coerência para expressar o contexto morfológico dessas vertentes. A classe 5 , que representa áreas planas, não foi identificada na região.

A classe IPT 4, representativa das posições de terço inferior das vertentes, possui correlação espacial com as áreas coluvionares da Serra do Mar. Lange Filho (2016) combinaram valores negativos do IPT, equivalentes à classe supramencionada, com os valores de declividade inferior a $7^{\circ}$ e vertentes com curvatura côncavasconvergentes, para a identificação de colúvios em relevo de mares de morros mamelonares. Neuman (2017) igualmente emprega valores negativos do IPT associado à curvatura côncava e declividade baixa para o mapeamento das áreas de depósito alúvio-coluvionares na Serra do Mar Paranaense.

Silveira (2015) aplicou o IPT para classificar formas de relevo na Serra da Prata, região central da Serra do Mar Paranaense. Para tanto, avaliou a combinação do IPT detalhado com IPT generalizado resultantes de distintas janelas amostrais circulares para análise, quais sejam: 1) raio de $60 \mathrm{~m}$ e $510 \mathrm{~m}$; 2) $105 \mathrm{~m}$ e 1005 ; 3) $195 \mathrm{~m}$ e $1695 \mathrm{~m}$. Foram destacados resultados satisfatórios, sendo o segundo que apresentou os limites mais fidedignos à morfologia do relevo local, apesar de erros de pequenos agrupamentos de classes, enquanto o primeiro foi o que produziu maior número de erros residuais e o último, com a generalização do raio, resultou em algumas classes desproporcionais com exagero de área, exemplo da classe de vales em U (SILVEIRA, 2015).

O recorte amostral 2 (figura 7) constitui a transição do Primeiro para o Segundo Planalto Paranaense - duas consagradas unidades naturais da paisagem paranaense já estabelecida em Maack (1968). Representa também o contato de duas Unidades Morfoestruturais e Morfoesculturais, conforme Santos et al. (2006), cujo limite estabelece à leste um conjunto de rochas metafóricas, onde sobressai em área o Grupo Açungui, do Proterozóico Superior, se identificando afloramentos das formações Votuverava e Capiru, compostas predominantemente pelos litotipos de filitos, mármores e quartzitos (FIORI; GASPAR, 1993) e, secundariamente, pela formação Camarinha e Complexo Gnáissico Migmatítico; enquanto à oeste é representado por arenitos devonianos da Formação Furnas, contidos na Bacia Sedimentar do Paraná - ampla região cratônica sedimentar do continente sul-americano recoberta na região central por espessas coberturas de lavas, resultantes de intenso vulcanismo fissural, associadas a uma intricada rede de diques cortando a inteira seção sedimentar e múltiplos níveis de soleiras intrudidas entre as camadas, cujo registro sedimentar e magmático é organizado em seis supersequências (MILANI et al., 2007).

$\mathrm{Na}$ área especificada se configura um típico relevo de cuesta, resultante do processo de circundesnudação pós-cretácea (Figura 8-A), que regionalmente, remetendo-se a idade do seu arcabouço geológico é denominada de Escarpa Devoniana, ou Escarpa do Purunã e Serrinha. Ao tratar das Regiões de circundesnudação pós- 


\section{ÍNDICE DE POSIÇÃO TOPOGRÁFICA (IPT) PARA CLASSIFICAÇÃO GEOMORFOMÉTRICA DAS FORMAS DE RELEVO NO ESTADO DO PARANÁ - BRASIL}

cretácea no Planalto Brasileiro, Ab'Saber (1949) considera que, no Paraná, as formações devonianas conformaram uma linha de cuestas de relativa expressão morfológica, destacando, posteriormente (AB'SABER, 1964) a existência de duas depressões periféricas no estado: uma situada nas terras baixas do Primeiro Planalto Paranaense, interdigitada à cuesta devoniana; e outra, na margem ocidental do Segundo Planalto Paranaense.

A Figura 7-A permite a identificação das formas de relevo predominantes no reverso da cuesta, situadas no Segundo Planalto, com as que prevalecem no front, no Primeiro Planalto Figura 8-A. Essa distinção também é perceptível na representação do relevo sombreado (Figura 7-B), onde as formas mais rugosas estão presentes no front dissecado pela ação erosiva dos rios obsequentes e subsequentes; enquanto as mais planas estão situadas no planalto do reverso proximal cuestiforme, sob ação dos rios consequentes.

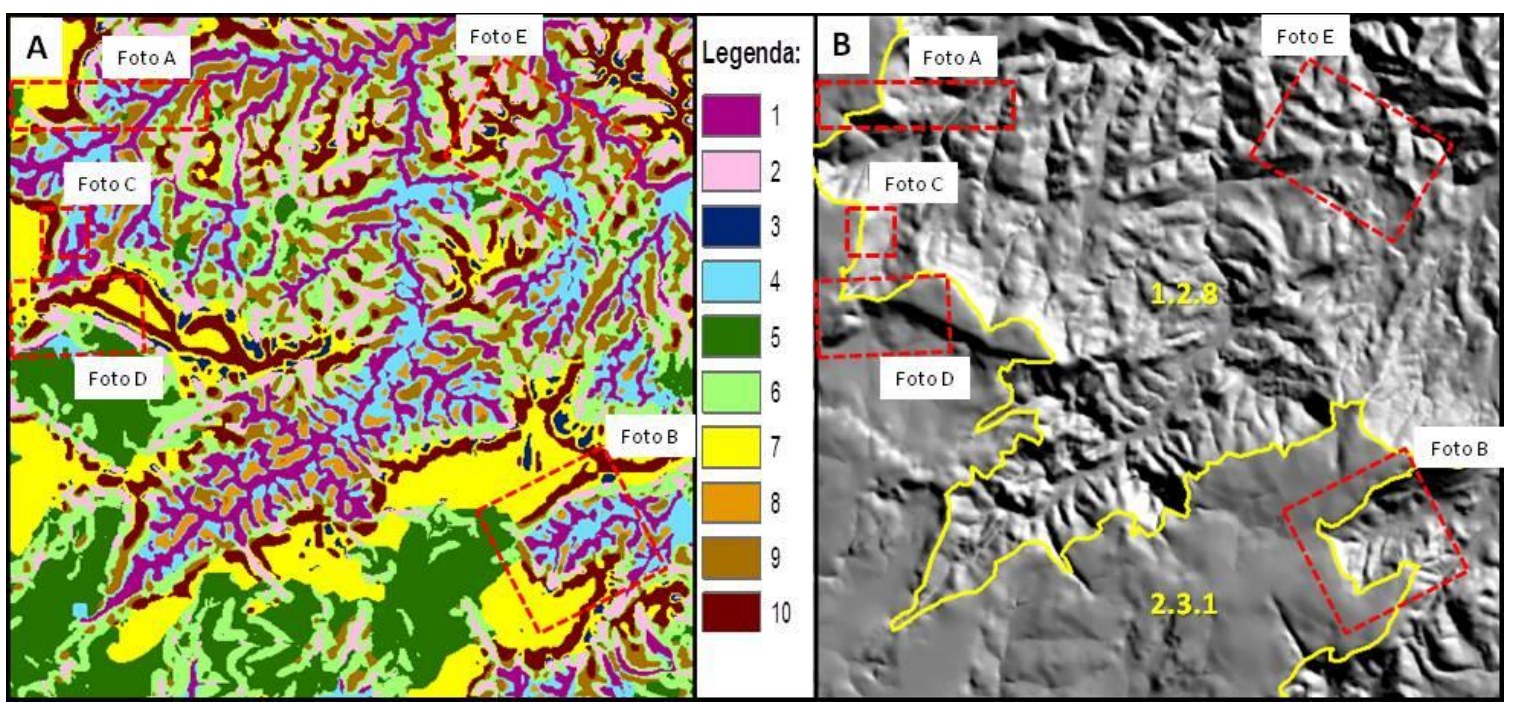

Figura 07 - Recorte da área 2 representa a transição do Primeiro para o Segundo Planalto Paranaense: A) formas de relevo identificadas pelo IPT; B) relevo sombreado - subunidades morfoesculturais: 1.2.8) Planalto Dissecado do Alto Ribeira e 2.3.1) Planalto de São Luís do Purunã. Os polígonos em cor vermelha situam as fotos de campo $A, B, C$ e D.

Legenda: 1) Fundos de vales com forte incisão da drenagem e cânions; 2) Vales rasos e áreas de drenagem situadas no terço médio das vertentes; 3) cabeceiras de drenagens; 4) áreas situadas nos terços inferiores das vertentes ou vales abertos e em forma de $U$; 5 ) áreas planas; 6 ) áreas situadas nas posições intermediárias das vertentes; 7) áreas situadas nas posições superiores das vertentes, patamares superiores ou mesas; 8) interflúvios secundários ou situados nas porções intermediárias das vertentes; 9) topos rebaixados, interflúvios, cristas intermediárias ou morros em áreas planas; 10) interflúvios elevados ou na forma de cristas elevadas e topos elevados.

No reverso da cuesta do Purunã, situados sobre a subunidade morfoescultural designada de Planalto de São Luís do Purunã (2.3.1), (Figura 7-B), predominam as classes do IPT 7, 5 e 6 , que podem ser observados na ilustração tridimensional do IPT da figura 9-A. A classe 7, nesse contexto, representa os patamares superiores que são sustentados pelos arenitos da Formação Furnas, representativos dos altos topográficas da região (primeiro plano da figura 8-D), apresentando elevação superior a $1050 \mathrm{~m}$, com os maiores valores alcançando $1200 \mathrm{~m}$ (figura 9-B) - caso representado no alto topográfico no lado esquerdo ao fundo da figura 8-B. Esses patamares superiores na escapa do Purunã constituem a superfície de aplanamento 


\section{SILVEIRA,C.T. E SILVEIRA, R.M.P. \\ ÍNDICE DE POSIÇÃO TOPOGRÁFICA (IPT) PARA CLASSIFICAÇÃO GEOMORFOMÉTRICA DAS FORMAS DE RELEVO NO ESTADO DO PARANÁ - BRASIL}

designada por Bigarella et al. (1978) e Bigarella (2003) como Pd3, também denominada de superfície do Purunã. Os relictos equivalentes a essa superfície encontram-se falhados e basculados na região da Serra do Mar, porém no contexto da área 2 foi representada pelas formas de relevo IPT 7, enquanto na área 1 , situada na Serra do Mar, foi melhor caracterizada pela classe IPT 10.

Na porção do front, sobre a subunidade morfoescultural Planalto Dissecado do Alto Ribeira (1.2.8), (Figura 7-B), a classe 7 representa formas de relevo com gênese distinta das identificadas no planalto de reverso. Se no relevo de reverso tabuliforme ou cuestiforme configuram patamares superiores e/ou mesas, na escarpa foi classificada na posição subjacente à cornija, área equivalente ao terço superior do tálus, enquanto nas áreas de morros e morrotes estão situadas de modo contiguo à jusante, circunvizinho da classe IPT 10, em posição de terço superior. (Figura 9-A). Na mesma abrangência do Primeiro Planalto as classes IPT 6 e 5 são menos evidentes em relação ao relevo do Segundo Planalto. O IPT 6, que representa as áreas situadas nas posições intermediárias das vertentes indicou correspondência com sua ocorrência nos morros, morrotes e escarpa, porém o IPT 5, que expressa as áreas planas, não mostrou eficiência nesse contexto (Figura 7-A).

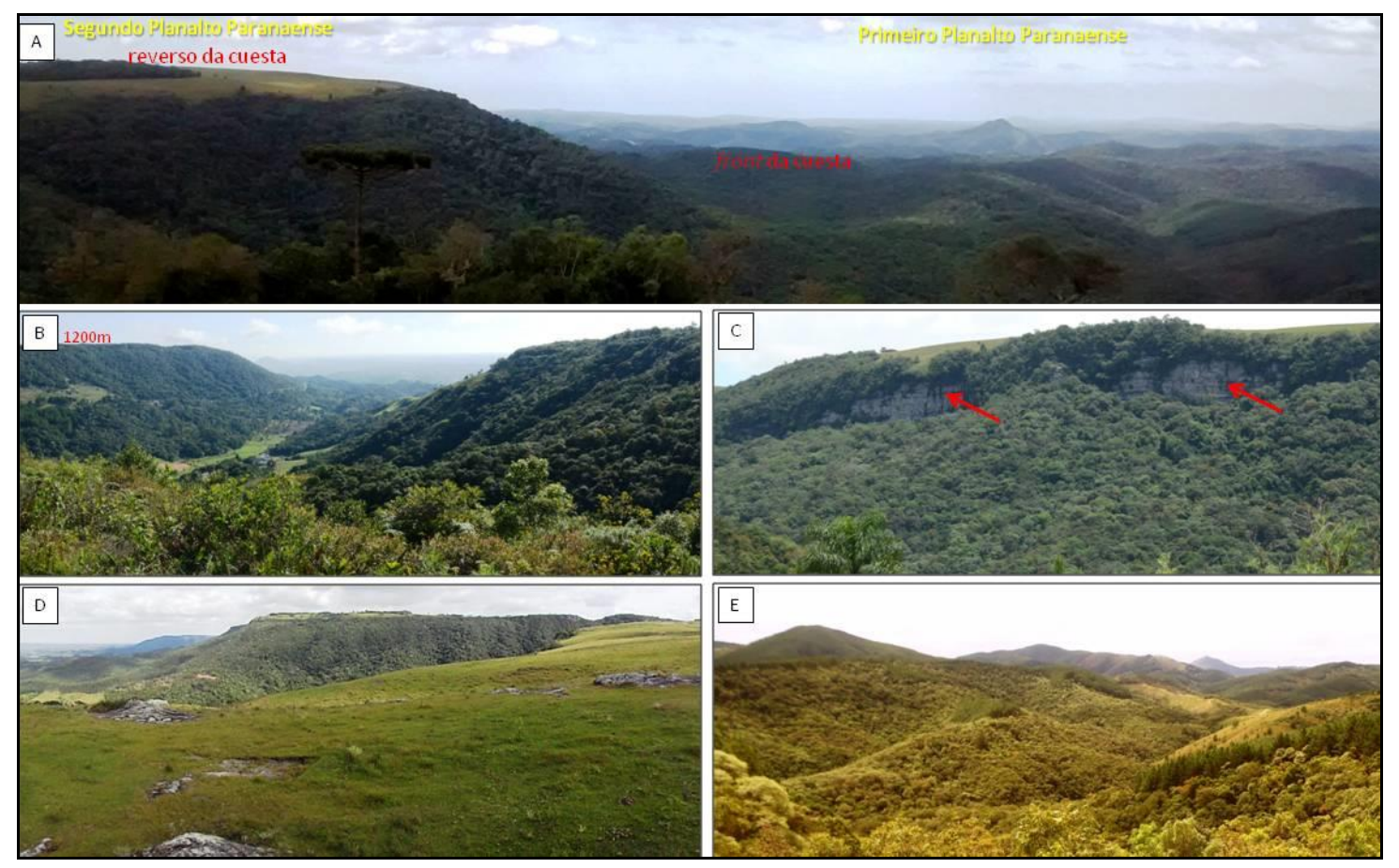

Figura 08 - Fotos ilustrativas do relevo na transição entre os Primeiro e Segundo Planaltos Paranaense. Fonte: Fotos obtidas no nível do solo pelos autores.

Na escarpa do Purunã, a classe IPT 10, referente à interflúvios elevados ou cristas elevadas, aparece continuamente no contato do front e reverso da cuesta (Figura 9-A), configurando a cornija, que por vezes expõe afloramento dos arenitos que constitui a litologia que a sustenta (Figura $8-\mathrm{C}$ ), com elevados valores de declividade, que configura a ruptura de declive dos patamares superiores (Figuras 8-A e C). A mesma classe quando situada no front, que constitui o Primeiro Planalto, aparece nas cimeiras, na forma de interflúvios elevados e topos elevados (Figura 9-A) que representam relevos residuais que foram ressalientados durante as fases de aplanamento subsequente (BIGARELLA, 2003), representadas pelas elevações no segundo plano da Figura 8-E. Esses interflúvios e topos elevados alcançam elevações entre $900 \mathrm{~m}$ e $940 \mathrm{~m}$, que para Stefanello (2011) essas cotas na região estariam relacionadas ao 


\section{SILVEIRA,C.T. e SILVEIRA, R.M.P. \\ ÍNDICE DE POSIÇÃO TOPOGRÁFICA (IPT) PARA CLASSIFICAÇÃO GEOMORFOMÉTRICA DAS FORMAS DE RELEVO NO ESTADO DO PARANÁ - BRASIL}

Pd1, apesar de que Bigarella (2003) destaca que a borda do [Primeiro] planalto possui notável relevo de cristas residuais relativos ao $\mathrm{Pd} 2$. Portanto a classe IPT 10 representa formas de relevo que se mostram distintas no Primeiro em relação ao Segundo Planalto.

Para representação das formas de relevo situadas nas posições elevadas que estão situadas no front, complementar à classe IPT 10, foram identificas as classes IPT 9 e 8 . A primeira abrange predominantemente os espigões do Primeiro Planalto e representa interflúvios, topos e cristas intermediárias, dando continuidade aos interflúvios elevados do IPT 10. A segunda, classe 8 , que constitui os interflúvios secundários ou situados nas porções intermediárias das vertentes e topos rebaixados, aparece de forma pouco expressiva, situados na posição do terço inferior dos divisores de água, em segmentos de vertente convexos-divergentes.

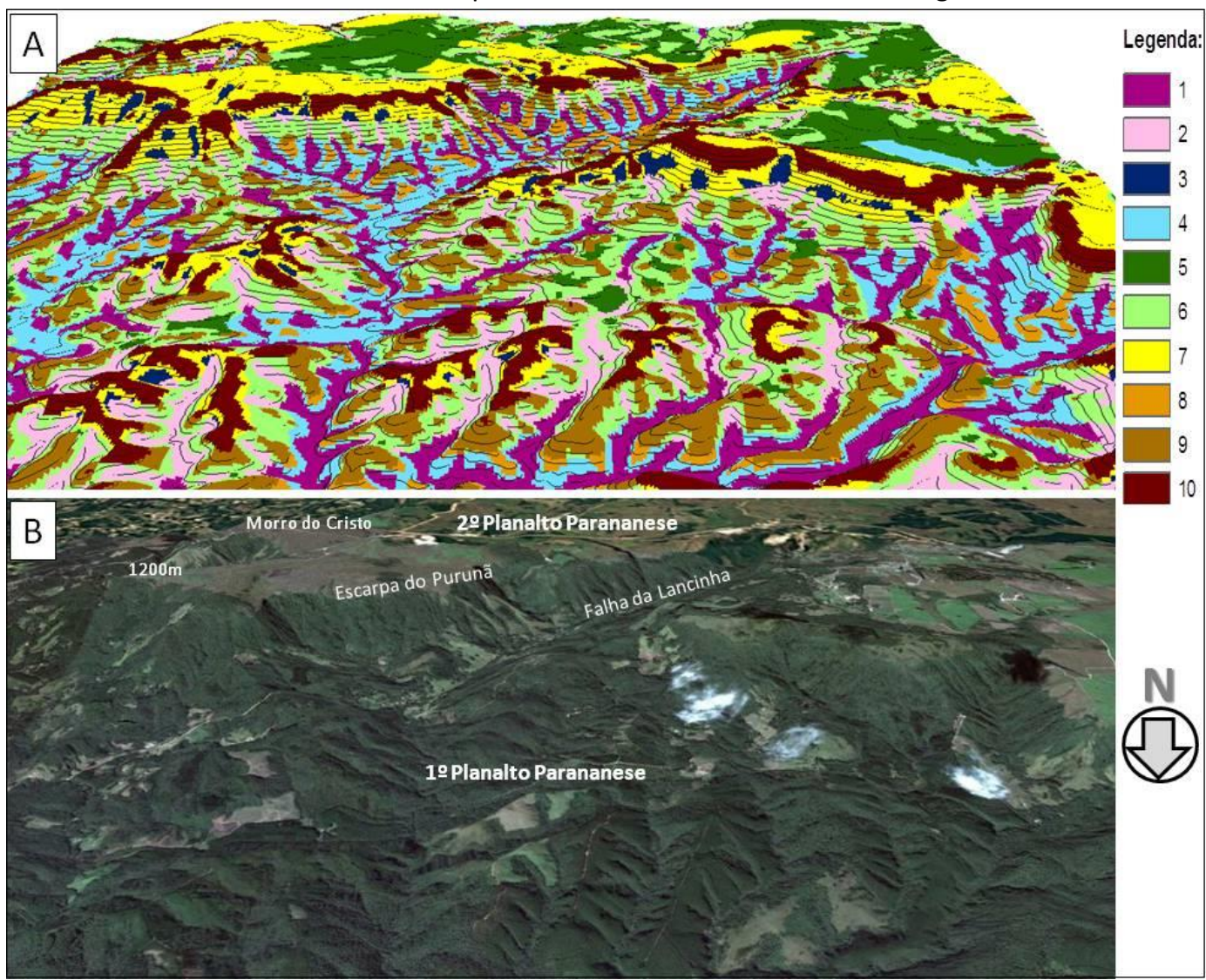

Figura 09 - Ilustração tridimensional da área 2, cuesta do Purunã: A) formas de relevo obtidas na classificação do IPT; B) Imagem de satélite obtida do Google Earth com exagero vertical de 2x.

As formas de relevo posicionadas nos vales, representadas pelas classes IPT 1, 2 e 3, apareceram exclusivamente no Primeiro Planalto. A classe 1 é a mais representativa, constitui os fundos de vales com forte incisão da drenagem e cânions, sendo associadas ao controle estrutural com direção preferencial para NE, determinados por sistemas de falhas, como exemplo representativo na área se tem a influência da Falha da Lancinha (FIORI; GASPAR, 1993) e, secundariamente, no sentido NW, é influenciado pelo Arco de Ponta Grossa. O controle na orientação pode ser verificado nas figuras 8-A e B. Essa classe é também representada pelos vales dos rios obsequentes que atuam diretamente na erosão remontante do front da escarpa do Purunã. A figura 6-B representa um vale obsequente, visto de montante para jusante.

A classe IPT 2 representa vales rasos e áreas de drenagem situadas no terço médio das vertentes, mostra-se contínua à classe IPT1, porém nas posições de jusante ou nas mais 


\section{ÍNDICE DE POSIÇÃO TOPOGRÁFICA (IPT) PARA CLASSIFICAÇÃO GEOMORFOMÉTRICA DAS FORMAS DE RELEVO NO ESTADO DO PARANÁ - BRASIL}

elevadas, abrangendo em alguns casos as nascentes e cabeceiras de drenagem quando estas estão situadas em posições mais baixas do relevo. A classe IPT 3 constitui as cabeceiras de drenagens dos cursos hidrográficos obsequentes que possuem suas nascentes na escarpa. Pelas distintas variações altitudinais da área 2 a classe 3 não representou as cabeceiras das elevações de morros e morrotes situados no Primeiro Planalto, nessas áreas a classe IPT 2 foi a que ocorreu (Figuras 7-A e 8-A).

As formas de relevo que configuram áreas situadas nos terços inferiores das vertentes ou vales abertos e em forma de U (IPT 4) foram identificadas predominantemente sobre 0 Primeiro Planalto, posicionadas junto aos fundos de vales, ocupando o entorno da classe IPT 1, em posições circunvizinhas de montante, representando as áreas coluvionares das encostas de morros e morrotes e no sopé da escarpa (Figura 10-A). Nesse mesmo ambiente foi fidedigno na representação do fundo do vale em $U$, ilustrado na Figura 9-C, cuja localização é expressa na Figura 7.
O terceiro recorte amostral, selecionado para avaliação da representação da classificação de formas de relevo por meio do IPT (Figura 10A), está situado na transição do Segundo para o Terceiro Planalto Paranaense, cujo limite marcado pelo realce topográfico da chamada Escarpa Triássico-Jurássica, também recebe denominações de Escarpa Mezosóica, Escarpa Arenito-basáltico, Escarpa do Serra Geral ou, como é comumente designada no Paraná, Escarpa da Serra da Esperança, ou da Boa Esperança. Ao longo dessa escarpa as deposições da formação Botucatu, sobrepostas à formação Pirambóia, estão recobertas pelos derrames basálticos da Formação Serra Geral, quando se tem a exposição das rochas efusivas da Formação Serra Geral sobre os sedimentos das formações paleozoicas. A linha da escarpa estende-se desde a República do Uruguai até o Estado de Goiás no território brasileiro, sendo que no Paraná se mostra continuamente de sul à norte. Para Ab'Saber (1949) a escarpa do Serra Geral constitui, em quase toda a sua extensão, um sistema de escarpas de circundesnudação, dos mais típicos e gigantes de que se tem notícia.

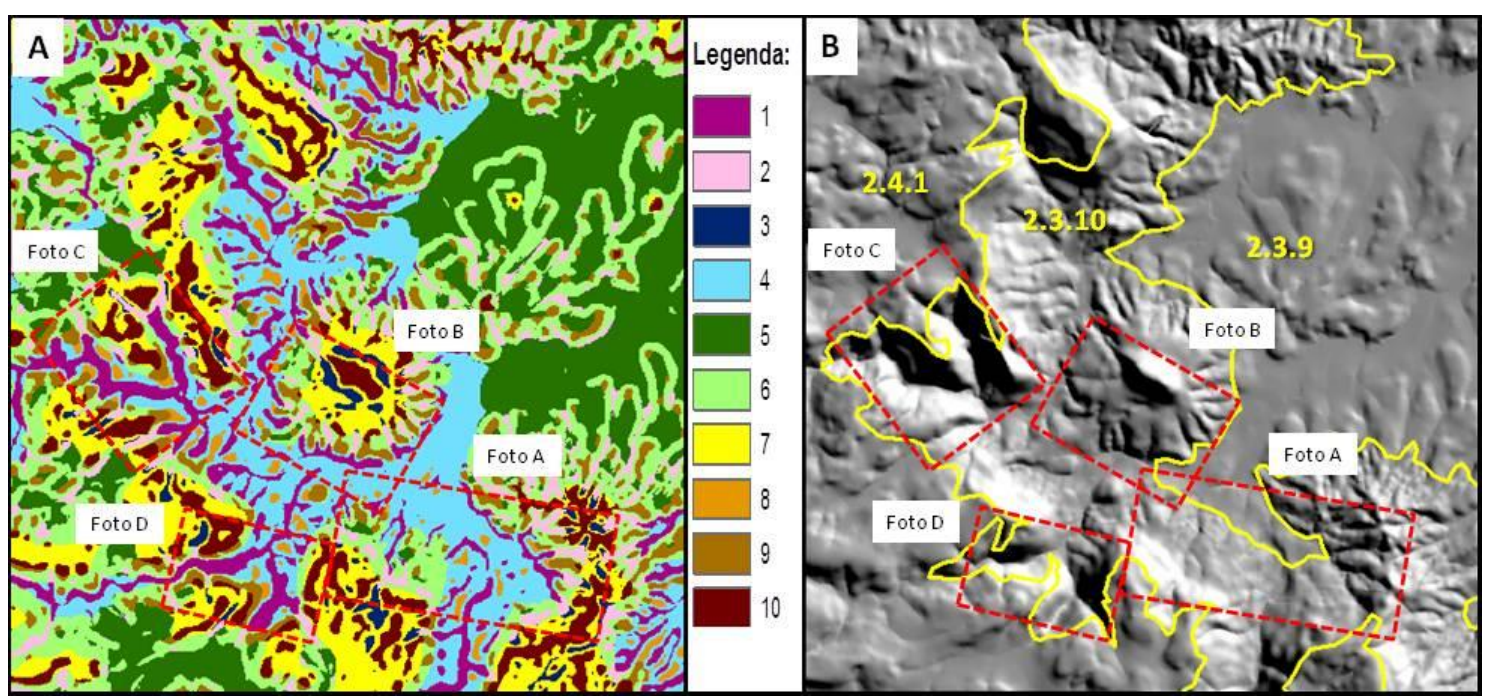

Figura 10 - Recorte da área 3 representa a transição do Segundo para o Terceiro Planalto Paranaense: A) formas de relevo identificadas pelo IPT; B) relevo sombreado - subunidades morfoesculturais: 2.4.1) Planalto Pitanga/Ivaiporã, 2.3.10) Planaltos Residuais da Formação Serra Geral e 2.3.9) Planalto de Prudentópolis. Os polígonos em cor vermelha situam as fotos de campo A, B, C e D.

Legenda: 1) Fundos de vales com forte incisão da drenagem e cânions; 2) Vales rasos e áreas de drenagem situadas no terço médio das vertentes; 3) cabeceiras de drenagens; 4) áreas situadas nos terços inferiores das vertentes ou vales abertos e em forma de $U ; 5)$ áreas planas; 6) áreas situadas nas 


\section{SILVEIRA,C.T. e SILVEIRA, R.M.P. \\ ÍNDICE DE POSIÇÃO TOPOGRÁFICA (IPT) PARA CLASSIFICAÇÃO GEOMORFOMÉTRICA DAS FORMAS DE RELEVO NO ESTADO DO PARANÁ - BRASIL}

posições intermediárias das vertentes; 7) áreas situadas nas posições superiores das vertentes, patamares superiores ou mesas; 8 ) interflúvios secundários ou situados nas porções intermediárias das vertentes; 9) topos rebaixados, interflúvios, cristas intermediárias ou morros em áreas planas; 10) interflúvios elevados ou na forma de cristas elevadas e topos elevados.

Próximo à escarpa Triássico-Jurássica ocorrem morros isolados (Figuras 11-C e 11-B), referentes a relevos isolados da Formação Serra Geral; e cristas controladas por diques e sills, ambos associados a Formação Serra Geral (MAACK, 1968) - denominados Planaltos Residuais da Formação Serra Geral (2.3.10), (SANTOS et al., 2006), (Figura 10-B). Na caracterização dessa mesma configuração do relevo, apresentada por Costa et al. (2005), à frente da serra da Esperança destaca inúmeros morros testemunhos e mesetas constituídos por arenitos das Formações Pirambóia e Botucatu e por rocha efusiva da Formação Serra Geral. Estes morros testemunhos guardam concordância topográfica com o topo da serra, indicando, hipoteticamente, a extensão inicial de derrames efusivos, de direção leste, possibilitando comparação ao ponto onde, atualmente, se localiza seu limite oriental.

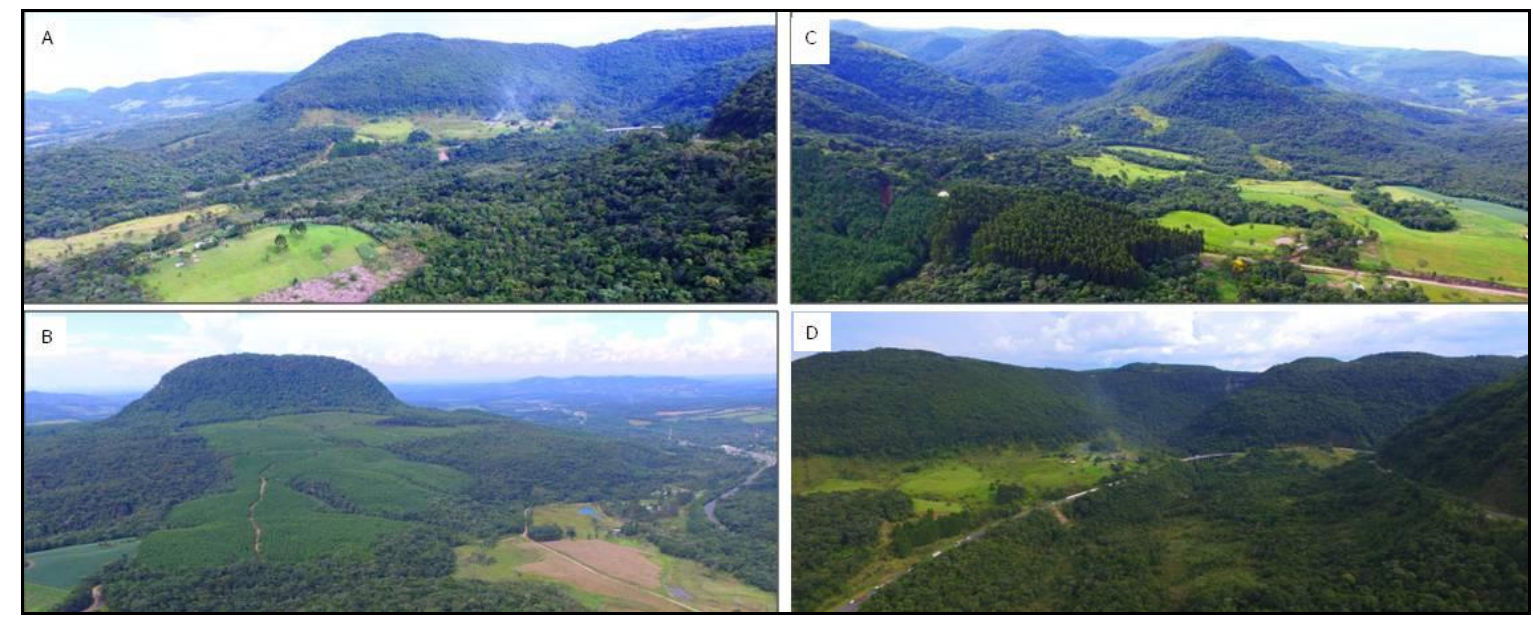

Figura 11 - Fotos ilustrativas do relevo na transição entre os Segundo e Terceiro Planaltos Paranaense. Fonte: Fotos obtidas em voo, com uso de um drone modelo Phantom 3, pelos autores.

Exemplo de destaque de morro testemunho que ocorre na área 3 é o chamado Morro do Chapéu, também designado como morro Morungava (Figura 11-B). Esse morro é formado pela litologia associada às camadas da Formação Rio do Rasto na base, sobrepostos por arenito da Formação Botucatu, com o topo sustentado por rochas eruptivas da Formação Serra Geral. Os topos desse morro, igualmente aos outros que aparecem na área amostral 3, situados próximos da escarpa, foram representados na classificação automatizada pela classe IPT 10 (Figura 10), que configura os interflúvios, cristas e/ou topos elevados, majoritariamente representam as formas de relevo encontradas nas elevações dos morros em posição proximal da escarpa no front da cuesta (Figura 12-A). Também nesses morros é onde foi identificado na área de estudo a classe IPT 3, que corresponde à cabeceiras de drenagens e nascentes (Figuras 10 e 12).

Segundo Ab'Saber (1949) no estado do Paraná existem duas depressões periféricas, ou subsequentes, uma situada nas terras baixas do Primeiro Planalto Paranaense, no front da cuesta devoniana, anteriormente apresentada; e outra, na margem ocidental do Segundo Planalto paranaense, no front da cuesta da Serra da Esperança. Nessa última, na posição proximal da escarpa, situado na subunidade morfoescultural 


\section{SILVEIRA,C.T. E SILVEIRA, R.M.P. \\ ÍNDICE DE POSIÇÃO TOPOGRÁFICA (IPT) PARA CLASSIFICAÇÃO GEOMORFOMÉTRICA DAS FORMAS DE RELEVO NO ESTADO DO PARANÁ - BRASIL}

Planaltos Residuais da Formação Serra Geral (SANTOS et al., 2006), prevalecem duas classes que são formas de relevo representativas nesse contexto geomorfológico, as classes 1 e 4 . A primeira constitui fundos de vales dos rios obsequentes que atuam no remonte erosivo da escarpa, enquanto que a segunda constitui as áreas adjacentes da primeira e configura o terço inferior das vertentes, próximo ao nível de base subsequente (Figuras 10-A e 12).

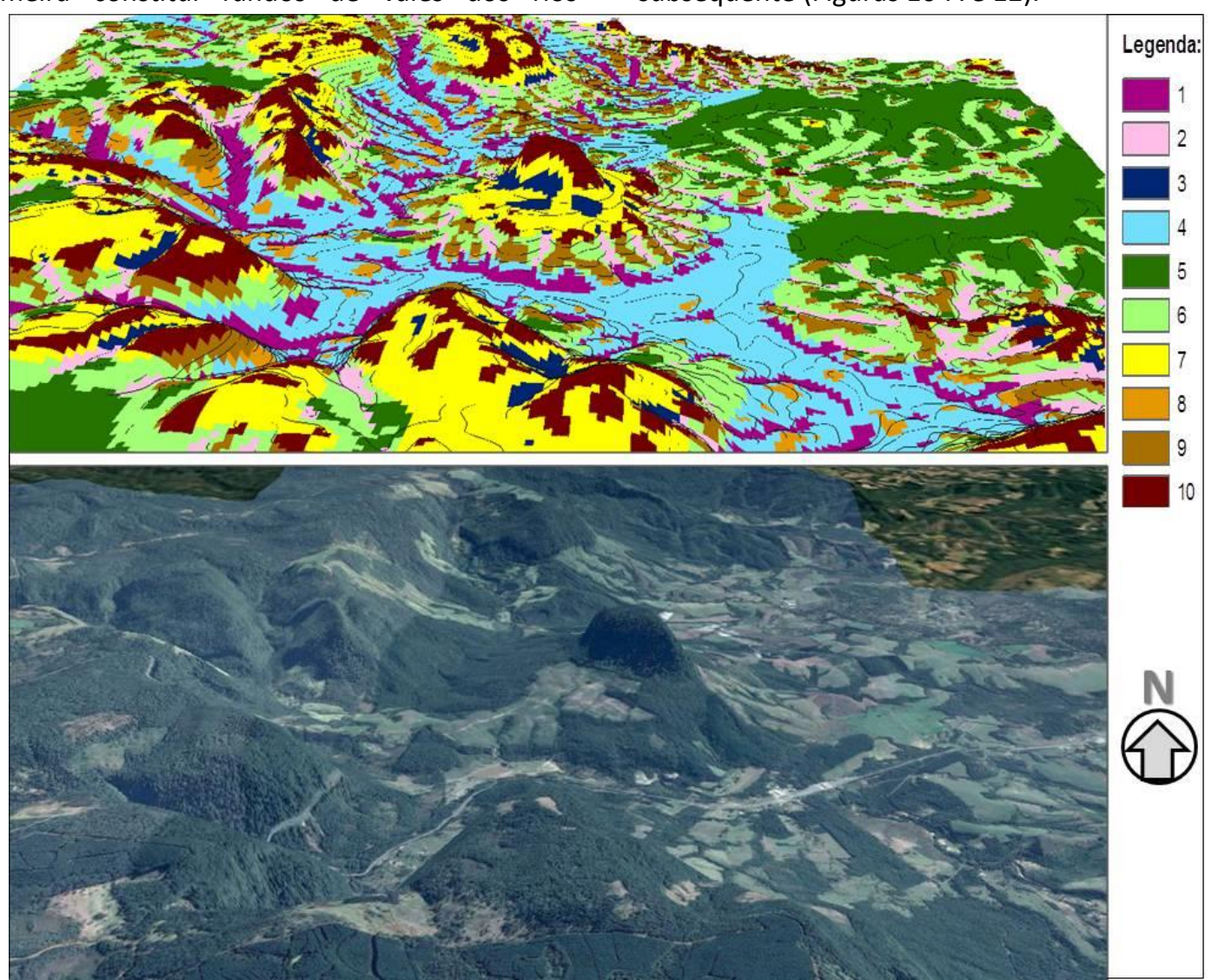

Figura 12 - Ilustração tridimensional da área 3, cuesta do Terceiro Planalto (Serra da Esperança) e Morro do Chapéu: A) formas de relevo obtidas na classificação do IPT; B) Imagem de satélite obtida do Google Earth com exagero vertical de $2 x$.

Nesse mesmo ambiente do front, porém sob a subunidade morfoescultural Planalto de Prudentópolis (2.3.9), (Figura 10-B), (SANTOS et al., op cit.), a área classificada como IPT 5, apesar de representar adequadamente as área planas da depressão erosiva subsequente, sob a perspectiva morfogenética é contínua das áreas situadas nos terços inferiores das vertentes ou representação dos vales abertos, identificados na classe IPT 4; desse modo a separação de ambas não foi eficiente, apesar de coerente sob a perspectiva morfométrica. As demais formas de relevo representadas foram as áreas situadas nas posições intermediárias das vertentes (classe 6); vales rasos e áreas de drenagem situadas no terço médio das vertentes (classe 2) e topos rebaixados (classe 9$)$.

O reverso da escarpa representa o Terceiro Planalto Paranaense, que abrange na área de estudo a subunidade morfoescultural Planalto Pitanga/Ivaiporã (2.4.1), (SANTOS et al., 2006), (Figura 10-B). Nessa área a classe IPT 7 expressa os patamares superiores e áreas situadas nas posições superiores das vertentes, proximal à linha da cuesta. Esses patamares e posições superiores correspondem, com base nos pressupostos de Bigarella (2003), às superfícies de erosão de cimeira ( $\mathrm{Pd} 3)$, representadas por planaltos residuais no reverso do Serra Geral (Figura 12). Ainda, na posição de reverso as 


\section{SILVEIRA,C.T. E SILVEIRA, R.M.P. \\ ÍNDICE DE POSIÇÃO TOPOGRÁFICA (IPT) PARA CLASSIFICAÇÃO GEOMORFOMÉTRICA DAS FORMAS DE RELEVO NO ESTADO DO PARANÁ - BRASIL}

demais classe do IPT representaram adequadamente as formas de relevo que lá ocorrem, com a presença de áreas planas, posições de terço inferior, intermediário e superior das vertentes e interflúvios.

O recorte amostral 4 (Figura 13) está situado no Terceiro Planalto Paranaense, predominantemente na subunidade morfoescultural Planalto do Alto/Médio Piquiri (2.4.5) e secundariamente no Planalto de Campo Mourão (2.4.10), segundo as unidades de relevo de Santos et al. (2006), (Figura 13-B), esculpidos sobre rochas eruptivas da Formação Serra Geral. Para Milani et al., (2007) o magmatismo Serra Geral faz parte da fase evolutiva Supersequência Gondwana III, um vulcanismo fissural constituindo por ampla província magmática que na BSP traduziu-se como uma espessa cobertura de lavas, com uma rede de diques cortando as camadas sedimentares e múltiplos níveis de soleiras intrudidas segundo os planos de estratificação. Recentemente a MINEROPAR (2013) apresentou a proposta de Grupo Serra Geral, com quatro formações e treze membros.

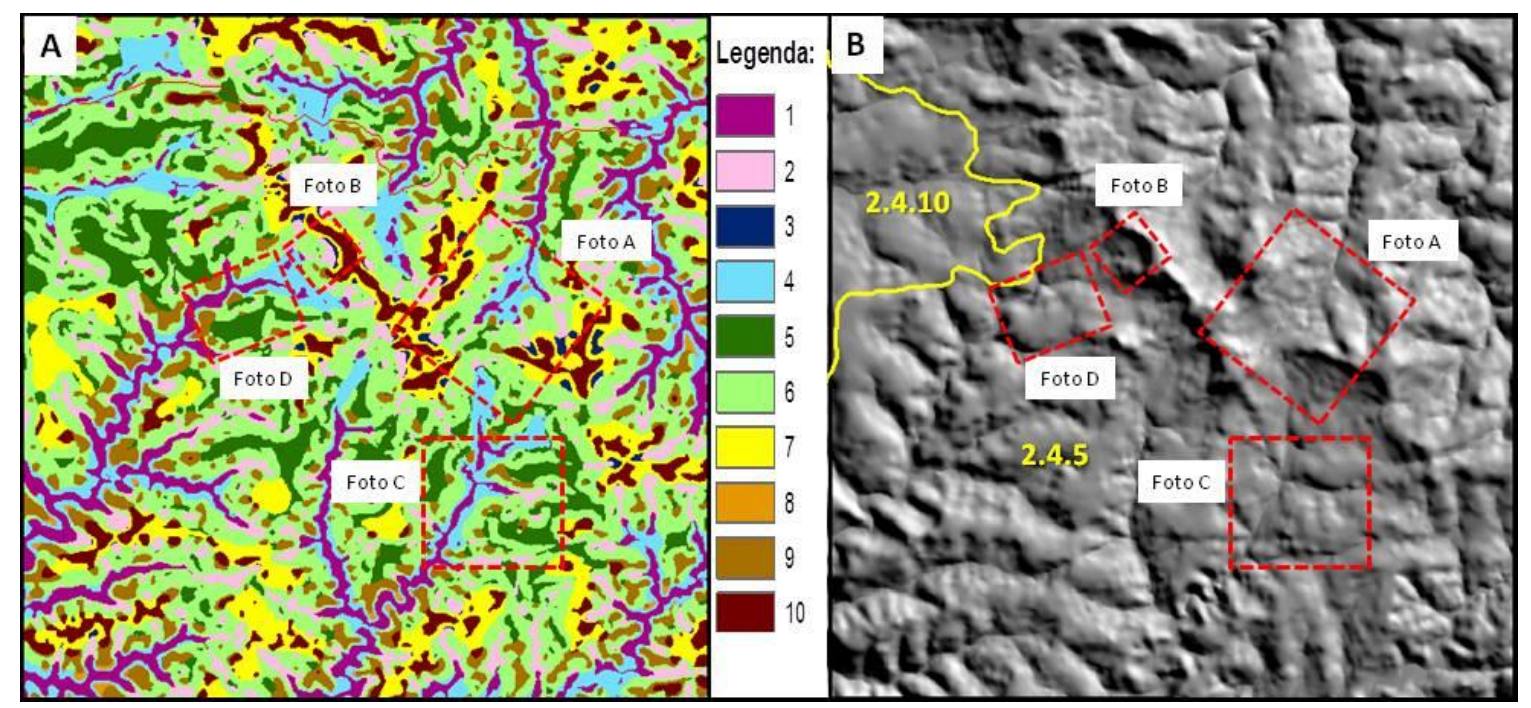

Figura 13 - Recorte da área 4 representa o Terceiro Planalto Paranaense sob a Formação Serra Geral: A) formas de relevo identificadas pelo IPT; B) relevo sombreado - subunidades morfoesculturais: 2.4.5) Planalto do Alto/Médio Piquiri e 2.4.10) Planalto de Campo Mourão. Os polígonos em cor vermelha apresentam a localização das fotos de campo A, B, C e D.

Legenda: 1) Fundos de vales com forte incisão da drenagem e cânions; 2) Vales rasos e áreas de drenagem situadas no terço médio das vertentes; 3) cabeceiras de drenagens; 4) áreas situadas nos terços inferiores das vertentes ou vales abertos e em forma de $U$; 5) áreas planas; 6) áreas situadas nas posições intermediárias das vertentes; 7) áreas situadas nas posições superiores das vertentes, patamares superiores ou mesas; 8) interflúvios secundários ou situados nas porções intermediárias das vertentes; 9) topos rebaixados, interflúvios, cristas intermediárias ou morros em áreas planas; 10) interflúvios elevados ou na forma de cristas elevadas e topos elevados.

Conforme o Mapa Geomorfológico elaborado pela Comissão Executora do Projeto RADAMBRASIL e publicado por IBGE (2005), a área está inserida na unidade geomorfológica do Planalto Dissecado do Rio Iguaçu - Rio Uruguai. Segundo Costa et al. (2005) essa unidade apresenta modelados resultantes dos processos de dissecação diretamente associados a fatores estruturais constituídos por sequências de derrames das rochas efusivas da Formação Serra Geral que se individualizaram por suas características morfológicas e petrográficas, bem como pelas variações internas presente em cada nível de derrame. As características estruturais, associadas à condições elevadas de umidade, possibilitou ação intempérica sobre zonas de 


\section{SILVEIRA,C.T. e SILVEIRA, R.M.P. \\ ÍNDICE DE POSIÇÃO TOPOGRÁFICA (IPT) PARA CLASSIFICAÇÃO GEOMORFOMÉTRICA DAS FORMAS DE RELEVO NO ESTADO DO PARANÁ - BRASIL}

maior fraqueza, inclusive propiciando o aparecimento de drenagem bem desenvolvida fatores condicionantes do modelado de dissecação diferencial; característico do recorte amostral em questão.

Nesse tipo de modelado a drenagem segue preferencialmente as linhas de fraqueza, condicionando vales estruturais típicos, que, por sua vez, possuem profundidade e formas variadas, em função da potência e gradiente do rio. Suas formas predominantes são em "V" aberto, ora em " $V$ " bem estreito e raramente em forma de "U. A forma do relevo é pautada por um interflúvio estreito, com topo plano ou levemente convexizado, segmentado por uma vertente de forte declive, configurando-se, ocasionalmente, como relevo escarpado, interrompidas, ao longo do declive, por patamares. Embora incipientes em algumas vertentes, em certas condições esses patamares são largos e planos, não ultrapassando, porém, $1.000 \mathrm{~m}$ de largura antes de nova ruptura de declive. Geralmente o desnível do patamar mais baixo é menos íngreme, gerando um nível de colinas com encostas rampeadas que convergem para diminutos terraços ou contiguamente a calha do rio (COSTA et al., 2005).

Nessa área a classificação por meio do IPT resultou em classes que expressaram adequadamente a morfologia do relevo na região (Figura 13), em acordo com a descrição da unidade geomorfológica e modelado apresentados por Costa et al. (2005) no relatório do Mapa Geomorfológico do IBGE (2005). A classe IPT 1 representou adequadamente os fundos de vales com forte incisão da drenagem dos principais rios, que podem ser verificados nas figuras $14-A$ e D; a classe 4 constitui as áreas situadas nos terços inferiores das vertentes, adjacente à ocorrência da classe 1 que configuram patamares inferiores, ou então, quando na ausência da classe 1 fazem a representação dos vales abertos com terraços; situados nas áreas de menor declividade.
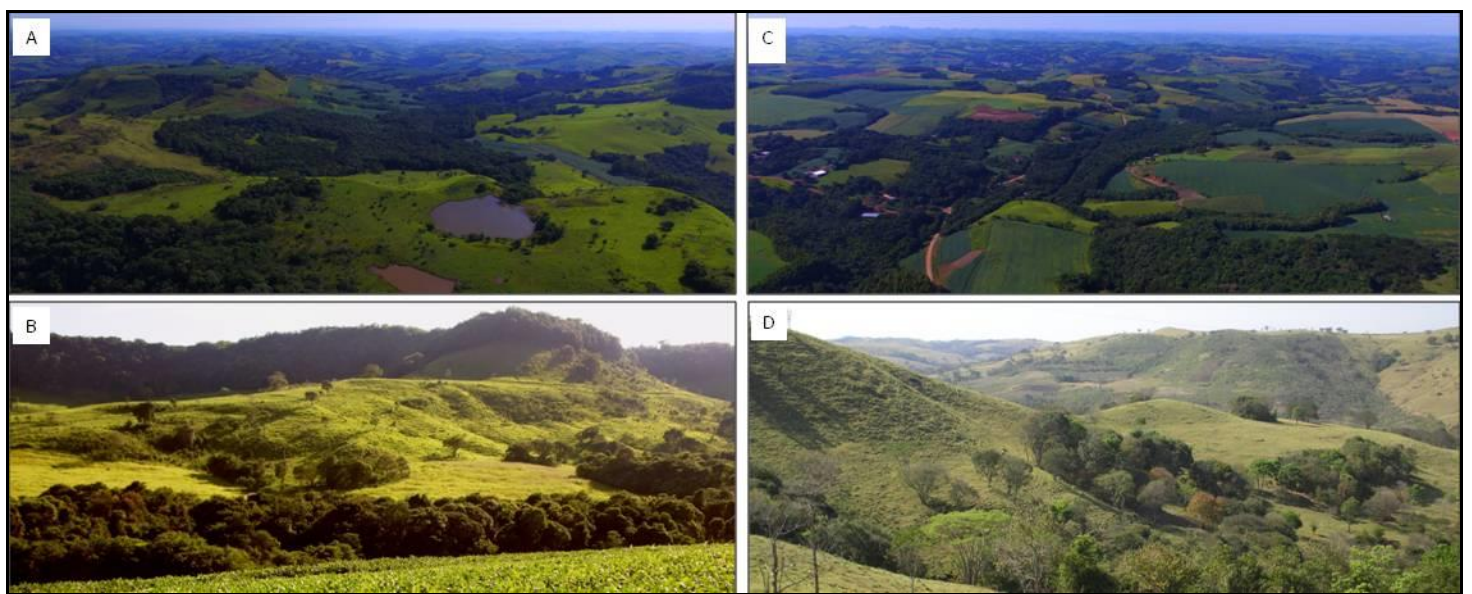

Figura 14 - Fotos ilustrativas do relevo em áreas situadas no Terceiro Planaltos Paranaense sobre rochas da Formação Serra Geral.Fonte: Fotos A e B obtidas em voo, com uso de um drone modelo Phantom 3, e fotos $\mathrm{B}$ e $\mathrm{C}$ obtidas no nível do solo, todas pelos autores.

As classes IPT 6 e 7, correlacionam-se, respectivamente, às áreas situadas nas posições intermediárias e superiores das vertentes, esta, ainda representando patamares superiores, também podendo ser compreendidos como patamares estruturais, uma vez que expressam a interferência das características geológicas (COSTA et al., 2005). A classe 10 configura os interflúvios elevados, sendo alguns deles os divisores de águas regionais das bacias dos rios Piquiri (localmente por meio de sua subbacia do rio Cantú) com o Tibagi (localmente representado por sua subbacia do rio Corumbataí), conformado pelos altos topográficos que estão ilustrados nas fotos das figuras 14-A e B. Esses altos topográficos são sustentados por influência 


\section{SILVEIRA,C.T. e SILVEIRA, R.M.P. \\ ÍNDICE DE POSIÇÃO TOPOGRÁFICA (IPT) PARA CLASSIFICAÇÃO GEOMORFOMÉTRICA DAS FORMAS DE RELEVO NO ESTADO DO PARANÁ - BRASIL}

estrutural geológica. Coincidente a esses altos é identificada uma unidade geológica distinta, referida por Mineropar (2013) como Membro Cantagalo (Figura 15); conjuntamente o Membro Flor da Serra do Sul representa igualmente

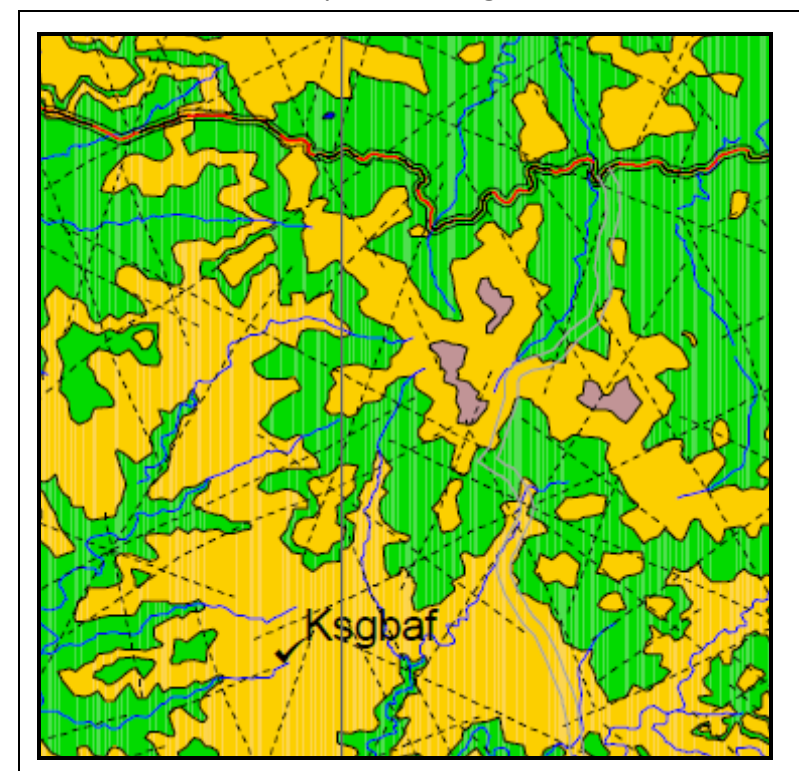

patamares superiores e interflúvios. Esses interflúvios e altos topográficos caracterizam as superfícies de cimeira, compreendidas como Pd3, conforme Bigarella (2003).

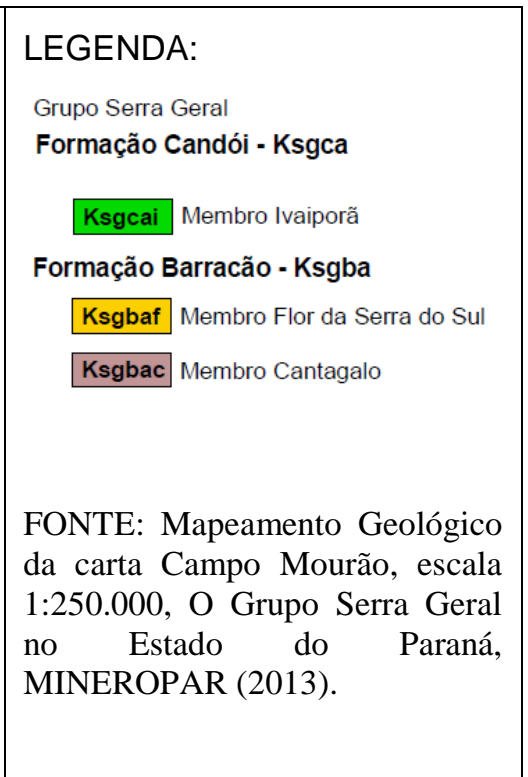

Figura 15 - Informações das unidades geológicas do Grupo Serra Geral mapeadas por MINEROPAR (2013), escala 1:250.000, correspondente ao recorte da área 4. Fonte: MINEROPAR (2013).

A classe IPT 3, relativa à cabeceiras de drenagem, se associa à interflúvios elevados (classe 10), e constitui as nascentes dos altos topográficos situada junto aos patamares superiores; enquanto as nascentes situadas nos patamares intermediários e drenagem situadas no terço médio das vertentes são representadas pela classe de IPT 2 (Figura 14-D)

Sem correspondências às planícies aluviais, o IPT 5 representa aquelas áreas planas que conjecturam patamares extensos, geralmente situados nos terços intermediários das vertentes; ou topos patamarizados situados em níveis altimétricos mais baixos que a classe 10 (Figura 14-C).

$\mathrm{Na}$ área amostral 4, em conformidade à constatação regional anteriormente tratada, constata-se que a distribuição das classes de formas de relevo obtidas pelo IPT têm ampla relação com as subunidades morfoesculturais, considerando que no Planalto de Campo Mourão (2.4.10) ocorreram apenas as classes 4, 5 e 6, enquanto no Planalto do Alto/Médio Piquiri (2.4.5) todas estão presentes, com maior destaque a classe 6 e de modo menos significativo as classes 3 e 8 . Por fim, é possível também perceber relação entre as classes de formas de relevo (Figura 13-A) com as unidades geológicas propostas pela Mineropar (2013), (Figura 15), sendo que no Membro Ivaiporã prevalecem as classes $1,4,5$ e 6, situadas nas posições de menor elevação da área; no Membro Flor da Serra do Sul as classes 2, 3, 7, 6, 8, 9 e 10 e no Membro Canta Galo a classe 10.

O critério para escolha da área compreendida no recorte amostral 5 justifica-se pela sua capacidade de demonstrar setores do estado onde o resultado da classificação automática de formas de relevo, mediante o IPT, foi insatisfatória; especificamente aquela situada na região noroeste do estado, sobre o Terceiro Planalto Paranaense, nas subunidades morfoesculturais Planalto de Paranavaí (2.4.11) e Planícies Fluviais (3.5.2), (Figura 16). 


\section{ÍNDICE DE POSIÇÃO TOPOGRÁFICA (IPT) PARA CLASSIFICAÇÃO GEOMORFOMÉTRICA DAS FORMAS DE RELEVO NO ESTADO DO PARANÁ - BRASIL}

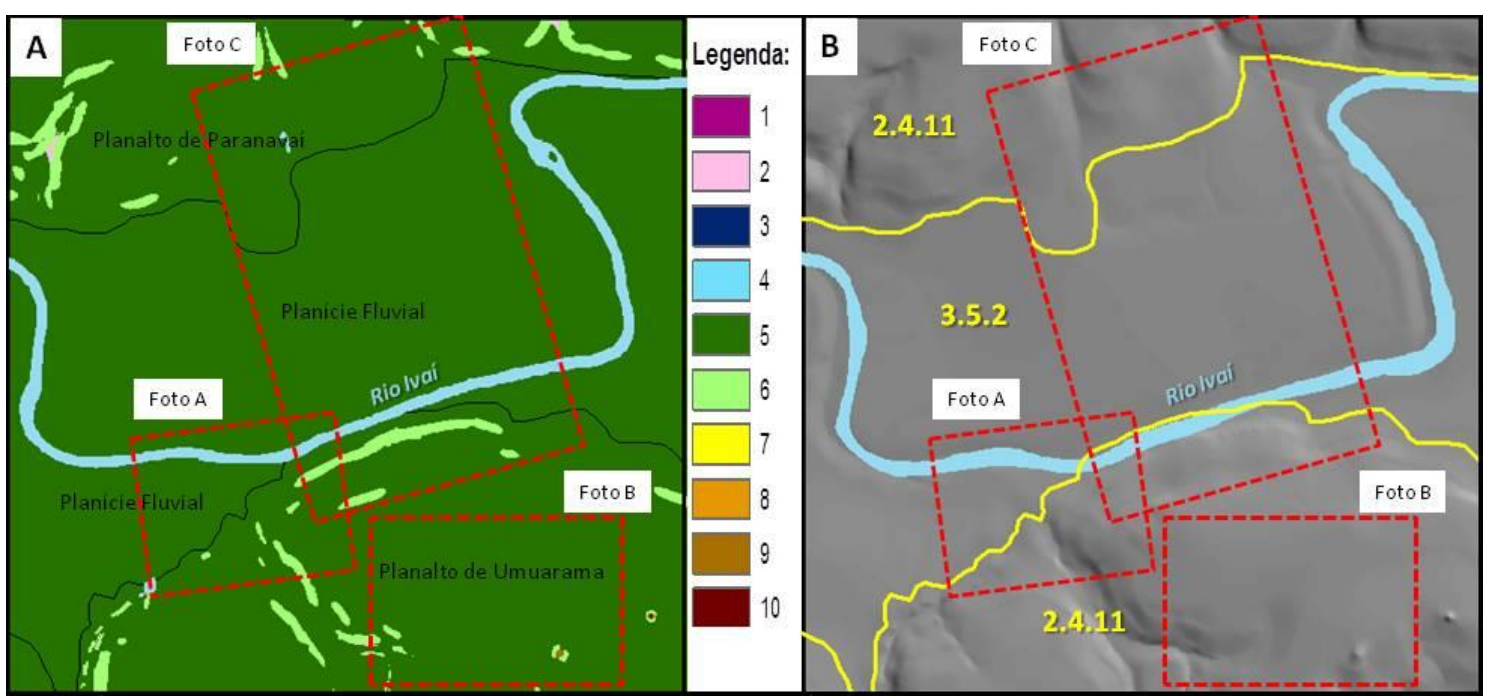

Figura 16 - Recorte da área 5 representa o Terceiro Planalto Paranaense sob a Formação Caiuá e nos sedimentos recentes das planícies: A) formas de relevo identificadas pelo IPT; B) relevo sombreado subunidades morfoesculturais: 2.4.11) Planalto de Paranavaí e 3.5.2) Planícies Fluviais. Os polígonos em cor vermelha situam as fotos de campo A, B e C.

Apesar dos quatro exemplos anteriormente apresentados terem evidenciado fidedignidade na separação das formas de relevo obtidas pela classificação automática do IPT, verificou-se limitação na representação na região mencionada, em decorrência do agrupamento da classe IPT 5 (áreas planas) com as vertentes e topos aplainados do Planalto de Paranavaí (Figura 16-B). Apesar dessa subunidade apresentar valores muito baixos de declividade, similarmente às planícies fluviais, constituem relevos distintos em termos morfológicos, morfogenéticos e morfodinâmicos.

A Figura 17 representa o relevo predominante da região noroeste do Paraná na subunidade 2.4.11, desenvolvida sobre os arenitos da Formação Caiuá, cuja geomorfologia da área caracteriza-se principalmente por colinas alongadas com topos abaulados, representando um modelado de dissecação homogênea (COSTA et al., 2005), com topos e interflúvios suavemente convexos com baixa declividade (Figura 20-B), que configura a subunidade morfoescultural Planalto de Paranavaí. Essas feições são caracterizadas por apresentarem baixa declividade e foram agrupadas, equivocadamente, com as planícies fluviais na classificação derivada do IPT (Figura 16-A), mesmo configurando distintos ambientes (Figuras 17-A e C), visto que as últimas são extensas áreas situadas em fundos de vale em ambiente agradacional com sedimentos recentes, enquanto as encostas do Planalto de Paranavaí são, ao contrário, ambientes degradacionais. 


\section{SILVEIRA,C.T. E SILVEIRA, R.M.P. \\ ÍNDICE DE POSIÇÃO TOPOGRÁFICA (IPT) PARA CLASSIFICAÇÃO GEOMORFOMÉTRICA DAS FORMAS DE RELEVO NO ESTADO DO PARANÁ - BRASIL}
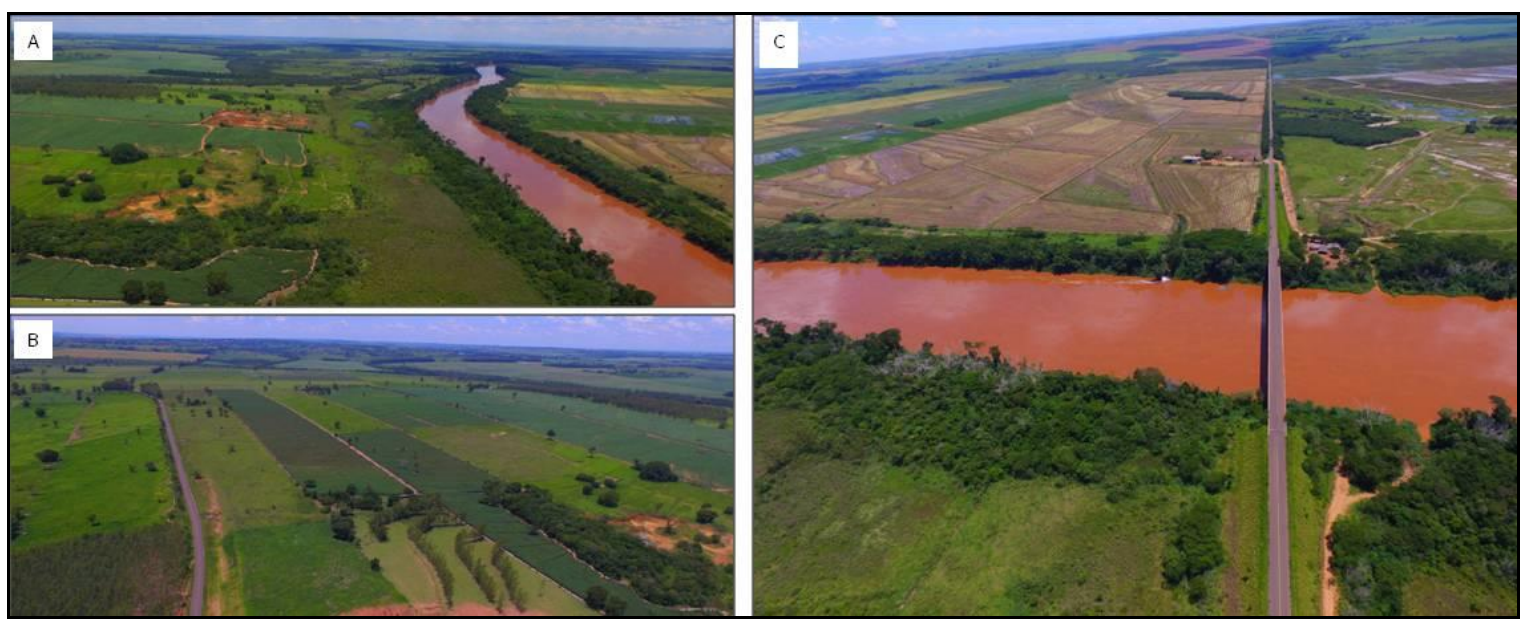

Figura 17 - Fotos ilustrativas do relevo em áreas situadas no Terceiro Planalto Paranaense sob a Formação Caiuá e as Planícies Fluviais. Fonte: Fotos obtidas em voo, com uso de um drone modelo Phantom 3, pelos autores.

As limitações verificadas na representação do relevo do Planalto de Paranavaí não necessariamente inviabilizam o uso da classificação do IPT nesta unidade, mas indicam a necessidade de ajustamento do tamanho das janelas de leitura para a detecção local, visto que foi aplicado um único tamanho de janela para todo o estado do Paraná. A afirmação é apoiada nos resultados satisfatórios obtidos por Gomes et al. (2016) que utilizaram o IPT com raio de $630 \mathrm{~m}$, combinado com a declividade, na região norte da subunidade do Planalto de Paranavaí (recorte da Carta topográfica MI 2726-4), onde se obteve oito classes de relevo com representação fidedigna (Figura 18).

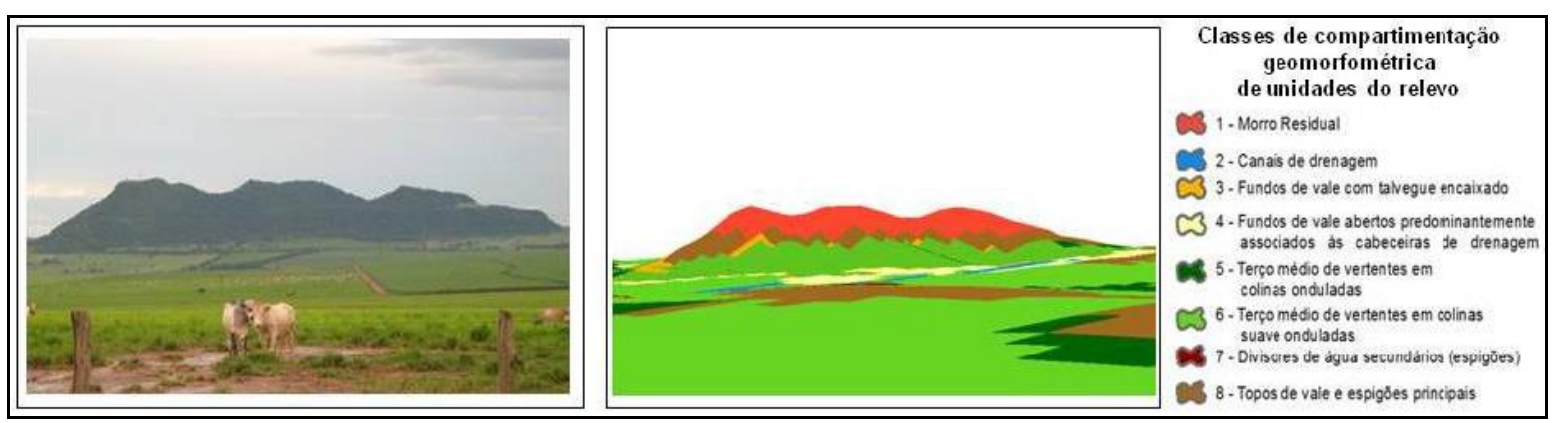

Figura 18 - Classes de relevo obtido com uso do IPT com raio de 630m combinado com a declividade, na região norte da subunidade do Planalto de Paranavaí. Fonte: Gomes et al. (2016)

Corroborando a afirmativa de influência do tamanho do raio na classificação do relevo, Silveira e Silveira (2014) ao aplicar a classificação do IPT com uma única janela de leitura para obtenção de seis classes de formas de relevo no Uruguai, ressaltaram que a definição do raio empregado na janela de leitura se mostrou mais decisivo na qualidade dos resultados, superando, inclusive, diferenças entre os três MDTs testados. Nesse sentido, Silveira e Silveira (2016) observaram que devido o IPT ser diretamente afetado pelo fator escala, os valores resultantes do índice e, consequentemente as classificações dele obtidas, variam de acordo com a dimensão de raio adotado na janela móvel de leitura. Desse modo, a etapa de definição do raio de análise da vizinhança, conforme apontam Tagil e Jenness (2008) e De Reu et al. (2013), deve estar associada ao nível de detalhe pretendido. 


\section{SILVEIRA,C.T. E SILVEIRA, R.M.P. \\ ÍNDICE DE POSIÇÃO TOPOGRÁFICA (IPT) PARA CLASSIFICAÇÃO GEOMORFOMÉTRICA DAS FORMAS DE RELEVO NO ESTADO DO PARANÁ - BRASIL}

\section{CONCLUSÕES}

Sob a perspectiva de análise do relevo em escala regional, as classes do índice de Posição Topográfica (IPT) demonstraram coerência com grandes unidades geomorfológicas homogêneas, corroborada pela quantificação estabelecida com as subunidades morfoesculturais do Mapeamento Geomorfológico do Estado do Paraná. Os agrupamentos predominantes das classes do IPT em cada compartimento corresponderam às suas características geomorfológicas que caracterizam distintos padrões de relevo.

Ademais, a grande potencialidade do IPT foi evidenciada pela análise local das classes obtidas. As dez formas de relevo mapeadas condizem com a realidade de campo destacada em quatro recortes amostrais distribuídos em porções representativas do estado do Paraná, sendo possível, inclusive, estabelecer relações entre as formas e suas respectivas gêneses e processos. Os recortes adotados para a análise evidenciaram, em sua maioria, áreas de transição entre grandes compartimentos, que apesar de serem naturalmente descontínuos, foram mapeados de modo fidedigno ao observado in loco.

Em apenas um recorte amostral verificou-se limitação do método. A limitação observada foi decorrente da adoção dos mesmos parâmetros indistintamente em todo o Paraná para o cálculo do IPT. Embora a proposta tenha evidenciado representatividade para os distintos compartimentos geomorfológicos do estado, a região noroeste foi a única que apresentou problemas em função das extensas vertentes com baixa declividade situadas em planaltos serem indistintas com as áreas de planícies.

Conquanto, a aplicação do IPT no estado do Paraná demonstrou a potencialidade de mapeamento automatizado de formas de relevo, pautado em critérios quantitativos para extensas áreas e com número reduzido de variáveis calculadas a partir de um MDT. Diferentemente de muitas propostas automatizadas que contemplam excessivo número de atributos topográficos e extensas regras de classificação, o IPT se mostrou simplificado e representativo para distintos contextos geomorfológicos, mesmo com a adoção de critérios unificados.

Nesse sentido, reforça-se que para a eficácia da proposta é necessário priorizar o rigor metodológico desde as etapas iniciais, referentes à aquisição da base e processamento do MDT, até as etapas de adoção dos parâmetros para cálculo de vizinhança, dos critérios e intervalos de discretização, da combinação dos IPTs e sua categorização.

Por fim, destaca-se que a aplicação do IPT associada a outras variáveis geomorfométricas, em estudos específicos, possui grande potencial como ferramenta auxiliar aos estudos de cartografia geomorfológica, tanto nas suas dimensões morfométricas e morfográficas quanto morfogenéticas, morfodinâmicas ou morfocronológicas.

\section{AGRADECIMENTOS}

Os autores agradecem ao Conselho Nacional de Desenvolvimento Científico e Tecnológico (CNPq) pela disponibilização de recursos, que possibilitou os levantamentos de campo, por meio do Projeto de Mapeamento do Estado do Paraná apoiado em análise digital do relevo, Processo 456244/2014-0.

\section{REFERÊNCIAS}

AB'SABER, A.N. Regiões de circundesnudação pós-cretácea, no Planalto Brasileiro. Boletim Paulista de Geografia, São Paulo, v. 1, p.1-21, 1949.

AB'SABER, A.N. O relevo brasileiro e seus problemas. In: Brasil - a terra e o homem, Org.: Aroldo de Azevedo. São Paulo: Companhia Editora Nacional. 1964

AB'SABER, A.N.; BIGARELLA, J.J. Considerações sobre a geomorfogênese da Serra do Mar no Paraná. Boletim Paranaense de Geografia, v. 4/5, p. 94-110, 1961.

ALMEIDA, F.F.M.; CARNEIRO, C.D.R. Origem e evolução da Serra do Mar. Revista Brasileira de Geociências, n.28, v.2, p.135-150, 1998.

BIGARELLA, J.J; BECKER, R.D; MATOS, D.J.; WERNER, A. A Serra do Mar e a porção oriental do Estado do Paraná: Um problema de segurança ambiental e nacional. Secretaria do Estado do Planejamento do Paraná: Curitiba. 1978.

BIGARELLA, J. J. Estruturação e origem das paisagens tropicais e subtropicais - volume 03 . Florianópolis: Ed. da UFSC, 2003. 


\section{SILVEIRA,C.T. E SILVEIRA, R.M.P. \\ ÍNDICE DE POSIÇÃO TOPOGRÁFICA (IPT) PARA CLASSIFICAÇÃO GEOMORFOMÉTRICA DAS FORMAS DE RELEVO NO ESTADO DO PARANÁ - BRASIL}

CHAGAS, C. S.; FERNANDES FILHO, E. I.; ROCHA, M. F.; CARVALHO JÚNIOR, W.; SOUZA NETO, N. C. Avaliação de modelos digitais de elevação para aplicação em um mapeamento digital de solos. Revista Brasileira de Engenharia Agrícola e Ambiental, v.14, n.2, p.218-226, 2010.

CHORLEY, R.J.; MAIM, D.E.C.; POGORZELSKI, .H.A. A new standard for measuring drainage basin shape. American Journal of Science, v. 255., p. 138-14, 1957.

COSTA, R.C.; BUSS, M.D.; ROSA, R.O. Capítulo 2 Geomorfologia. In: Levantamento de Recursos Naturais, Volume 35: folha SG.22 Curitiba, parte da folha SG.21 Asunción e folha SG.23 Iguape (Relatório técnico do extinto Projeto RADAMBRASIL), Org. Instituto Brasileiro de Geografia e Estatística (IBGE), Rio de Janeiro, 2005.

DE REU, J.; BOURGEOISA, J.; BATSA, M.; ZWERTVAEGHERB, A.; GELORINIB, V.; SMEDTC, P.; CHUE, W.; ANTROPD, M.; MAEYERD, P.; FINKEB, P.; MEIRVENNEC, M.; VERNIERSB, J.; CROMBÉA, P. Application of the topographic position index to heterogeneous landscapes. Geomorphology, n. 186, p. 39-49, 2013.

DIKAU, R.; BRABB, E. E.; MARK, R. M. Landform Classification of New Mexico by Computer. Open File report 91-634. U.S. Geological Survey, 1991.

DIKAU, R.; BRABB, E. E.; MARK, R. K.; PIKE, R. J. Morphometric landform analysis of New Mexico. Zeitschrift fur Geomorphologie Supplementband. v. 101, p. 109-126, 1995.

DRAGUT, L; BLASCHKE, T. Automated classification of landform elements using objectbased image analysis. Geomorphology, v. 81, p. 330-344, 2006.

EL-SHEIMY, N.; VALEO, C.; HABIB, A. Digital Terrain Modelling: Acquisition, Manipulation and Applications. Artech House, Inc., NorwoodMassachusetts. 2005.

ESRI. ArcGis: Arcmap e extensão Spatial Analyst. Versão 10.1. Environmental Systems Research Institute, 2010.

FIORI, A.P; GASPAR, L.A. Considerações sobre a estratigrafia do Grupo Açungui (Proterozóico Superior), Paraná, sul do Brasil. Bol. IG-USP, Sér. Cient., n. 24, p. 1-19, 1993.

GROHMANN, C.H.; RICCOMINI, C.; STEINER, S.S. Aplicações dos modelos de elevação SRTM em geomorfologia. Revista Geografia Acadêmica, v.2 n.2, p. 73-83, 2008.

GOMES, S.M.A; SILVEIRA, C.T.; SILVEIRA, R.M.P. Compartimentação geomorfométrica de unidades de relevo das cartas mi 2726-4 e Mi 2820-2 - estado do Paraná. In: Anais do XI Simpósio Nacional de Geomorfologia, Maringá PR, 2016.

HENGL, T. Pedometric mapping: bridging the gaps between conventional and pedometric approaches. Wageningen University, Enschede, 2003. 233p. PhD thesis.

HORN, B. K. P. Hill shading and the reflectance map. Proceedings of the IEEE, v.69, n.1, p.14-47, 1981.

IPPOLITI, G. A.; COSTA, L.M.; SCHAEFER, C. E .G. R.; FERNANDES FILHO, E. I.; GAGGERO, M. R.; SOUZA, E. Análise digital do terreno: ferramenta na identificação de pedoformas em microbacia na região de "Mar de Morros" (MG). Revista Brasileira de Ciência do Solo, v.29, p.269-276, 2005.

IWAHASHI, J.; PIKE, R. J. Automated classifications of topography from DEMs by an unsupervised nested-means algorithm and a three-part geometric signature. Geomorphology, v. 86, p. 409-440, 2007.

JASIEWICZ, J.; STEPINSKI, T. F. Geomorphons a Pattern Recognition Approach to Classification and Mapping of Landforms. Geomorphology, v. 182, p. 147-156, 2013.

JULESZ, B. Textons, the Elements of Texture Perception, and Their Interactions. Nature. v. 290. p. 91-97, 1981.

JULESZ, B. A Brief Outline of the Texton Theory of Human Vision. Trends in Neuroscience, v. 7, p. 41-45, 1984.

KLINGSEISEN, B.; METTERNICHT, G.; PAULUS, G. Geomorphometric landscape analysis using a semi-automated GIS-approach. Environmental Modelling \& Software Xx, p. 1-13, 2007.

LANGE FILHO, G.; SILVEIRA, C. T. da. Mapeamento geomorfométrico da bacia hidrográfica do Zendron, Blumenau - SC. Revista Equador, v.4, n.3. ed. esp. 2, p. 854-863, 2015.

LANGE FILHO, G. Caracterização e mapeamento dos modelados padrões e formas de relevo simbolizadas da bacia hidrográfica do ribeirão Itoupava, Blumenau - SC. Dissertação de 


\section{SILVEIRA,C.T. E SILVEIRA, R.M.P. \\ ÍNDICE DE POSIÇÃO TOPOGRÁFICA (IPT) PARA CLASSIFICAÇÃO GEOMORFOMÉTRICA DAS FORMAS DE RELEVO NO ESTADO DO PARANÁ - BRASIL}

Mestrado. Universidade Federal do Paraná (Programa de Pós-Graduação em Geografia). Curitiba, 2016. 131 p.

LI, Z.; ZHU, Q.; GOLD, C. Digital Terrain Modeling: Principles and Methodology. Boca Raton: CRC Press, 2005.

LIAO, W. H. Region Description Using Extended LocalTernary Patterns. 20th International Conference on Pattern Recognition, p. 10031006, 2010.

MACMILLAN, R. A.; PETTAPIECE, W. W.; NOLAN, S. C.; GODDARD, T. W. A generic procedure for automatically segmenting landforms into landform elements using DEMs, heuristic rules and fuzzy logic. Fuzzy Sets and Systems 113, p. 81-109, 2000.

MACMILLAN, R. A.; SHARY, P. A. Landform and landform elements in geomorphometry. In: HENGL, T.; REUTER, H. I. (eds.) Geomorphometry - Concepts, Software, Applications, Series Developments in Soil Science vol. 33, Amsterdam: Elsevier, p. 227-254, 2009.

MAACK, R. Geografia Física do Estado do Paraná. Curitiba: Banco de Desenvolvimento do Estado do Paraná, Universidade Federal do Paraná e Instituto de Geologia e Pesquisas Tecnológicas, 1968.

MARK, D. M., SMITH, B. A science of topography: from qualitative ontology to digital representations. In: Bishop, M.P., Shroder, J.F. (Eds.), Geographic Information Science and Mountain Geomorphology. Springer-Praxis, Chichester, England, p. 75-97, 2004.

MARTINONI, D. Models and experiments for quality handling in digital terrain modelling. Ph.D. Thesis. University of Zürich, 2002.

MIHAI, N. Geomorphometric techniques for landform analysis for pedologic characterization of terrain. Annals of the University of Craiova Agriculture, Montanology, Cadastre Series. Vol. XLII-2012/1, p. 454-460, 2012.

MILANI, E.J.; MELO, J.H.G.; SOUZA, P.A.; FERNANDES, L.A.; FRANÇA, A.B. Bacia do Paraná. Boletim de Geociências da Petrobras, v.15. n.2, p. 265-287, 2007.

MINEROPAR - MINERAIS DO PARANÁ S.A. O Grupo Serra Geral no Estado do Paraná Mapeamento Geológico das cartas 1:250.000 de Guaíra, Cascavel, Campo Mourão, Foz do Iguaçu,
Guaraniaçu, Guarapuava Pato Branco e Clevelândia. Curitiba: volume 1 - texto e volume 2 - anexos, 2013.

MOORE, I. D.; GRAYSON, R. B.; LADSON, A. R. Digital terrain modeling: a review of hydrological, geomorphological, and biological applications. Hydrological Processes. v.5, n.1, p.3-30, 1991.

NASCIMENTO, E.R.; SALAMUNI, E.; QUEIROZ, G.L.; SILVA, P.A.H.; FIORI, A.P. Evidências de determinação morfotectônica e neotectônica no relevo da Serra do Mar no estado do Paraná. Revista Brasileira de Geomorfologia, v.14, n.3, p. 287-299, 2013.

NEUMAN, G. Classificação de unidades morfológicas por análise digital do relevo na porção sudeste do Paraná. Dissertação de Mestrado. Universidade Federal do Paraná (Programa de Pós-Graduação em Geografia). Curitiba, 2017.

PENNOCK, D. J. Terrain attributes, landform segmentation, and soil redistribution. Soil and Tillage Research, v.69, n. 1-2, p.15-26, 2003.

PIKE, R. J. Geomorphometry - diversity in quantitative surface analysis. Progress in Physical Geography. v. 24, n. 1, p. 1-20, 2000.

PIKE, R. J.; EVANS, I., HENGL, T. Geomorphometry: A Brief Guide. In: HENGL, T.; REUTER, H. I. (eds.) Geomorphometry - Concepts, Software, Applications, Series Developments in Soil Science. Amsterdam: Elsevier, v. 33, p. 3-30, 2009.

REUTER, H. I. ArcGis Geomorphometry Toolbox: Version 1.0.2. Gisxperts GBR, Germany, 2009.

ROBAINA, L.E.S; TRENTIN, R.; LAURENT, F. Compartimentação do estado do Rio Grande do Sul, Brasil, através do uso de geomorphons obtidos em classificação topográfica automatizada. Revista Brasileira de Geomorfologia, São Paulo, v.17, n.2, p.287-298, 2016.

ROMSTAD, B. Improving relief classification with contextual merging. Proceedings of ScanGIS'2001 - The 8th Scandinavian Research Conference on Geographical Information Science. Ås, Norway, p. 3-13, 2001.

SAADAT, H.; BONNELL, R.; SHARIFI, F.; MEHUYS, G.; NAMDAR, M.; ALE-EBRAHIM, S. Landform classification from a digital elevation model and 


\section{SILVEIRA,C.T. E SILVEIRA, R.M.P. \\ ÍNDICE DE POSIÇÃO TOPOGRÁFICA (IPT) PARA CLASSIFICAÇÃO GEOMORFOMÉTRICA DAS FORMAS DE RELEVO NO ESTADO DO PARANÁ - BRASIL}

satellite imagery. Geomorphology, v. 100, p. 453464, 2008.

SAMPAIO, T.V.M. AUGUSTIN, C.H.R.R. Índice de Concentração da Rugosidade: uma nova proposta metodológica para o mapeamento e quantificação da dissecação do relevo como subsídio a cartografia geomorfológica. Revista Brasileira de Geomorfologia, v. 15, n. 1, p. 47-60, 2014.

SANTOS, L.J.C.; OKA-FIORI, C.; CANALI, N.E.; FIORI, A.P.; SILVEIRA, C.T.; SILVA, J.M.F.; ROSS, J.L.S. Mapeamento geomorfológico do Estado do Paraná. Revista Brasileira de Geomorfologia, v. 7, n. 2, p. 3-12, 2006.

SCHMIDT, J.; DIKAU, R. Extracting geomorphometric attributes and objects from digital elevation models - semantics, methods, future needs. In: DIKAU, R.; SAURER, H. (Eds.), GIS for Earth Surface Systems - Analysis and Modelling of the Natural Environment. p. 153173, 1999.

SHARY, P. A.; SHARAYA, L. S.; MITUSOV, A. V. Fundamental quantitative methods of land surface analysis. Geoderma, v.107, n.1-2, p.1-32, 2002.

SILVEIRA, C.T. Análise digital do relevo na predição de unidades preliminares de mapeamento de solos: integração de atributos topográficos em sistemas de informações geográficas e redes neurais artificiais. Tese de doutorado. Universidade Federal do Paraná (Programa de Pós-Graduação em Geografia). Curitiba. 2010. 152 p.

SILVEIRA, R.M.P. Análise digital do relevo como apoio para a cartografia geomorfológica da porção central da Serra do Mar Paranaense. Dissertação de Mestrado. Universidade Federal do Paraná (Programa de Pós-Graduação em Geografia). Curitiba, 2015. 123 p.

SILVEIRA, R.M.P.; SILVEIRA, C.T. Clasificación morfológica del relieve uruguayo basada em modelos digitales de elevación y técnicas morfométricas. Geografía y Sistemas de Información Geográfica. (GESIG-UNLU, Luján). Año 6, N 6, Sección I: 19-36, 2014.

SILVEIRA, R.M.P.; SILVEIRA, C.T.; OKA-FIORI, C. Emprego de técnicas de inferência espacial para identificação de unidades de relevo apoiado em atributos topográficos e árvore de decisão.
Revista Brasileira de Geomorfologia, v. 15, no 1 , 87-101, 2014.

SILVEIRA, R. M. P.; SILVEIRA, C. T. Classificação hierárquica automatizada de formas do relevo no estado do Paraná apoiada na modelagem digital do terreno. Revista Brasileira de Geografia Física, v. 08, n. 05, p. 1509-1523, 2015a.

SILVEIRA, R. M. P.; SILVEIRA, C. T. Análise comparativa entre Modelos Digitais de Elevação com distintas características de processamento e aquisição. Boletim de Geografia, Maringá, v. 33, número especial, p. 106-121, $2015 b$.

SILVEIRA, R. M. P.; SILVEIRA, C. T. Análise digital do relevo aplicada à cartografia geomorfológica da porção central da Serra do Mar Paranaense. Revista Brasileira de Geomorfologia , v. 17, no 4, 615-629, 2016.

SIRTOLI, A. E.; SILVEIRA, C. T.; MONTOVANI, L. E.; SIRTOLI, A. R. A.; OKA-FIORI, C. Atributos do relevo derivados de modelo digital de elevação e suas relações com solos. Scientia agraria, v.9, n.3, p.317-329, 2008.

SPEIGHT, J. G. Parametric description of land form. In: G. A. Stewart (Ed.), Land evaluation, p. 239-250. Australia: Macmillan, 1968.

TAGIL, S.; JENNESS, J. GIS-Based Automated Landform Classification and Topographic, Landcover and Geologic Attributes of Landforms Around the Yazoren Polje, Turkey. Journal of Applied Sciences, n. 8 v. 6, p. 910-921, 2008.

TINÓS, T.M.; FERREIRA, V.V.; RIEDEL, P.S.; ZAINE, J.E. Aplicação e avaliação de metodologia de classificação automática de padrões de formas semelhantes do relevo. Revista Brasileira de Geomorfologia, v.15, n.3, p.353-370, 2014.

TRENTIN, R.; ROBAINA, L. E. S.; SILVEIRA, C. T. Compartimentação geomorfométrica da bacia Hidrográfica do rio Itú/RS. Revista Brasileira de Geomorfologia, v.16, n.2, p.219-237, 2015.

TRICART, J. Principes et méthodes de la géomorphologie. Paris: Masson Ed., 201p., 1965.

TOBLER, W. R. The development of analytical cartography - a personal note. Cartography and Geographic Information Science. n. 27, v. 3, p.189-194, 2000.

VALERIANO, M.M. Modelo digital de elevação com dados SRTM disponíveis para a América do Sul. Instituto Nacional de Pesquisas Espaciais, p. 1-72, 2004. 


\section{ÍNDICE DE POSIÇÃO TOPOGRÁFICA (IPT) PARA CLASSIFICAÇÃO GEOMORFOMÉTRICA DAS FORMAS DE RELEVO NO ESTADO DO PARANÁ - BRASIL}

VASCONCELOS. V.; CARVALHO JÚNIOR, O. A.; MARTINS, E. S. COUTO JUNIOR, A. F.; GUIMARÃES, R. F.; GOMES, R. A. T. Sistema de classificação geomorfométrica baseado em uma arquitetura sequencial em duas etapas: árvore de decisão e classificador espectral, no Parque Nacional Serra da Canastra. Revista Brasileira de Geomorfologia, v. 13, n. 2, p. 171-186, 2012.

WEISS, A. Topographic Position and Landforms Analysis. Poster presentation, ESRI User Conference, San Diego, CA, 2001.

WILSON, J. P. Digital terrain modelling. Geomorphology, 137, p.107-121, 2012.

WILSON, J. P.; GALLANT, J. C. (eds.). Terrain analysis: principles and applications. New York: John Wiley \& Sons, p.1-27, 2000.

WOOD, J. The geomorphological characterisation of digital elevation models. Leicester, UK, 1996. 185p. PhD Thesis - University of Leicester. Disponível em: http://www.soi.city.ac.uk/ jwo/phd.

ZHOU, Q.; LEES, B.; TANG, G. (eds.). Advances in Digital Terrain Analysis. Series: Lecture Notes in Geoinformation and Cartography. Berlim: Springer-Verlag, 2008 